\title{
Characteristics of airborne water-soluble organic carbon (WSOC) at a background site of the North China Plain
}

\author{
Yuanyuan Luo ${ }^{\mathrm{a}}$, Xuehua Zhou ${ }^{\mathrm{a}, *}$, Jingzhu Zhang ${ }^{\mathrm{a}}$, Likun Xue ${ }^{\mathrm{a}}$, Tianshu Chen ${ }^{\mathrm{a}}$, Penggang Zheng ${ }^{\mathrm{a}}$, \\ Jingjing Sun ${ }^{\mathrm{a}}$, Xiaolong Yan ${ }^{\mathrm{b}}$, Guangxuan Han $^{\mathrm{c}}$, Wenxing Wang ${ }^{\mathrm{a}}$ \\ ${ }^{a}$ Environment Research Institute, Shandong University, Qingdao 266237, Shandong Province, China \\ ${ }^{\mathrm{b}}$ College of Chemistry, Chemical Engineering and Materials Science, Shandong Normal University, Jinan 250014, Shandong Province, China \\ ${ }^{\mathrm{c}}$ Key Laboratory of Coastal Environmental Process and Ecology Remediation, Yantai Institute of Coastal Zone Research, Chinese Academy of Sciences, Yantai, Shandong, \\ China
}

\section{A R T I C L E I N F O}

\section{Keywords:}

WSOC

ALW

Acidity

Light absorption

PSCF

\begin{abstract}
A B S T R A C T
Water-soluble organic carbon (WSOC), a significant part of organic carbon (OC) in fine particles, can alter the hygroscopic properties of aerosols and affect global climate change. In this study, $\mathrm{PM}_{2.5}$ filter samples were collected in 2017 winter and summer to investigate the secondary formation, sources and light absorption properties of WSOC. The average WSOC/OC was $66 \%$ with the higher value in summer (74\%). There are strong correlations between WSOC and secondary components like secondary organic carbon (SOC) and inorganic ions while the correlation between WSOC and EC was weak, indicating secondary formation contributed a dominant portion to WSOC at this site. Moreover, high aerosol liquid water (ALW) and particle acidity were found to enhance the secondary formation of WSOC. The sources of WSOC investigated with Positive Matrix Factorization model (PMF) demonstrated that secondary formation was dominated with $59.9 \%$ in winter and $77.9 \%$ in summer. The absorption Ångstrom exponents (AAE) were 6.88 in winter and 9.15 in summer. The MAE 365 in winter $\left(1.32 \mathrm{~m}^{2} \mathrm{~g}^{-1}\right)$ was higher than that in summer $\left(0.38 \mathrm{~m}^{2} \mathrm{~g}^{-1}\right)$, indicating the stronger light absorption ability of WSOC in winter. The radiative forcing of WSOC by light absorption corresponded to only 1-10\% of that caused by EC. The potential source contribution function (PSCF) identified inland cities in Shandong province, eastern Henan and Jiangsu province as major source regions of WSOC. The findings from this study imply a critical role of secondary formation characteristics of WSOC at the regional background site of the North China Plain.
\end{abstract}

\section{Introduction}

Atmospheric fine particulate matter $\left(\mathrm{PM}_{2.5}\right.$, with aerodynamic diameters $\leq 2.5 \mu \mathrm{m}$ ) is one of the most concerning environmental issues in China due to its effects on climate and human health (Fang et al., 2015; Hasheminassab et al., 2014; Zhang et al., 2017a). Carbonaceous species are a significant fraction of ambient fine particles and can be divided into elemental carbon (EC) and organic carbon (OC) according to their thermal and optical properties. Organic aerosol (OA), the main component of carbonaceous species, plays an important role in global climate change both directly and indirectly via affecting the radiative forcing or cloud formation (Hallquist et al., 2009; Kanakidou et al., 2005; Pöschl et al., 2010). OC includes a vast array of chemical species which are directly emitted into the atmosphere (primary OC, POC) or formed through chemical transformation of primary volatile organic compounds to semi-volatile products then partitioning into the condensed phase (secondary OC, SOC). Most organic species are harmful to human health.

OC may be divided into water-soluble organic carbon (WSOC) and water-insoluble organic carbon (WISOC). WSOC is a critical constituent, accounting for approximately $20-80 \%$ of OC (Du et al., 2014a; Kirillova et al., 2013; Zhang et al., 2017b). WSOC exerts significant effects on radiative forcing and climate change because some components of WSOC, e.g., water-soluble brown carbon $(\mathrm{BrC})$ and humic-like substances (HULIS), have light absorption properties (Baduel et al., 2010; Duarte et al., 2005; Teich et al., 2016). In addition, WSOC also has an impact on the hygroscopic properties of aerosols that could influence cloud condensation nuclei (CCN) (Asa-Awuku et al., 2009). Besides, some possible health risks are linked to WSOC since it contains a variety of organic components (Ma et al., 2019; Park and Cho, 2011;

\footnotetext{
* Corresponding author.

E-mail address: xuehuazhou@sdu.edu.cn (X. Zhou).
} 
Verma et al., 2015; Zhao et al., 2019). Most forms of WSOC are oxygenated organic compounds such as carboxylic acids, alcohols and aldehydes directly emitted from primary sources and/or formed through secondary processes via homogenous or heterogeneous oxidation (Blando and Turpin, 2000; Decesari et al., 2006). A wide spectrum of field measurements have shown that WSOC is strongly correlated with SOA estimated by other methods including the oxygenated organic aerosol (OOA) method (Xiao et al., 2011) and the chemical mass balance model (Snyder et al., 2009). Besides, the concentration of WSOC agreed well with the secondary water-soluble ions such as sulfate, nitrate and oxalate (Du et al., 2014a). These all provide an evidence that WSOC is closely associated with SOA formation (Anderson et al., 2008; Rengarajan et al., 2011; Sullivan and Weber, 2006). Another, some studies found that WSOC could also be from primary sources such as vehicle emission and biomass burning, and these primary sources could contribute a considerable proportion of WSOC in some regions (Hecobian et al., 2010; Viana et al., 2008).

WSOC has been frequently measured worldwide due to its significant role in atmospheric science (Anderson et al., 2008; Hodas et al., 2014; Pathak et al., 2011; Teich et al., 2016). The North China Plain, with a regional GDP contribution of $38.4 \%$ in China (China Statistical Yearbook, 2017), has experienced rapid economic development in recent years, which has led to severe air pollution. The Yellow River Delta National Nature Reserve (YRDNNR), located in the Bohai economic zone of the North China Plain, is an ecological protection zone with an area of 153,000 ha. The pollution sources near YRDNNR are fewer, indicating less local emission influence. The Beijing-Tianjin-Hebei (BTH) region where the air quality is worse in China (Wang et al., 2018) is located in the northwest of YRDNNR, and the Yangtze River Delta is located in the southeast of YRDNNR. In winter, the frequent north/ northwest winds can bring air pollutants from the North China Plain to the sampling site (Yao et al., 2016; Yuan et al., 2014; Zhang et al., 2018b), while in summer, south/southeast winds are dominant which might bring massive pollutants from Yangtze River Delta regions (i.e., Shanghai, Zhejiang and Jiangsu provinces). This unique geographical location and meteorological condition make YRDNNR an ideal background site to study regional transport of fine particles in the North China Plain (Yao et al., 2016; Yuan et al., 2014). However, few studies concerning WSOC have been carried out in the area. Hence, a comprehensive investigation focusing on the characteristics and sources of WSOC at YRDNNR is necessary. This paper presents a seasonal variation of WSOC characteristics in winter and summer at YRDNNR, China. Furthermore, the primary and secondary nature, the source apportionment and the light absorption properties of WSOC are also discussed.

\section{Methods}

\subsection{Sampling}

Field research was conducted at the Yellow River Delta Ecological Research Station of Coastal Wetland, Chinese Academy of Sciences (CAS) $\left(37^{\circ} 76^{\prime} \mathrm{N}, 118^{\circ} 98^{\prime} \mathrm{E}\right)$ at YRDNNR, Dongying, Shandong Province from 17 February to 21 March (winter) and 10 June to 10 July (summer), 2017. The sampling site is a background site with few nearby stationary sources of fine particulate matter, $45 \mathrm{~km}$ away from Dongying City. The nearest polluted area is a small town with a population of about 25,000 , located in the southwest of the sampling site, $15 \mathrm{~km}$ away. Dongying owns one of the most important oil fields in China and some oil fields are located in the north and southwest of the station with average distances $>15 \mathrm{~km}$. A total of $118 \mathrm{PM}_{2.5}$ samples along with 4 blank samples were collected using a medium flow intelligent sampler (TH-150A, Wuhan Tianhong Environmental Protection Industry Co., Ltd) at a flow rate of $100 \mathrm{~L} / \mathrm{min}$. Samples were collected every half day (from 8:00 a.m. to 19:30 p.m. and from 20:00 p.m. to 7:30 a.m. the next day). All the quartz filters ( $1 \mu \mathrm{m}$ pore size and $88 \mathrm{~mm}$ diameter, Pall Gelman Inc.) were pre-baked at $600{ }^{\circ} \mathrm{C}$ for $2 \mathrm{~h}$ to eliminate organic compounds before sampling. After sampling, the filters were stored in a refrigerator at $-18^{\circ} \mathrm{C}$ before any chemical analysis. All the data presented in the study were blank-corrected.

The meteorological parameters including relative humidity (RH), temperature, wind speed and wind direction were measured every 5 min with a portable automatic weather station (PC-4, Jinzhou Sunshine Technology Co. Ltd., China) during both the winter and summer campaigns.

\subsection{Sample analysis}

$\mathrm{PM}_{2.5}$ mass concentrations were determined using an electronic balance (Sartorius ME-5F, sensitivity: $1 \mu \mathrm{g}$ ). OC and EC were measured using a thermal-optical transmittance (TOT) carbon analyzer (Sunset Laboratory Tigard, OR, USA) and the heating program was NIOSH870. The detailed procedure has been described elsewhere (Panteliadis et al., 2015). The detection limit is $0.2 \mu \mathrm{g} \mathrm{cm}^{-2}$. OC/EC were usually determined by the operation methods. Thus, here OC and EC concentrations had potential uncertainties (Supplement materials).

WSOC was determined using Vario Total Organic Carbon Cube (Elementar, Germany). Water-soluble ions, including $\mathrm{Cl}^{-}, \mathrm{SO}_{4}{ }^{2-}$, $\mathrm{NO}_{3}{ }^{-}, \mathrm{NH}_{4}{ }^{+}, \mathrm{Na}^{+}, \mathrm{K}^{+}, \mathrm{Mg}^{2+}$ and $\mathrm{Ca}^{2+}$, were analyzed by a Dionex IC90 Ion Chromatograph (Dionex Corporation, CA, USA). The IonPac AS14A column and IonPac CG12A column were adopted to analyze anions and cations, respectively. The measurements of WSOC, watersoluble inorganic ions and UV/Vis-spectrometer used aqueous extracts of $\mathrm{PM}_{2.5}$. The preparation of aqueous extracts and the methods on sample analysis were described in Supplement materials.

\subsection{Measurement of the light absorption spectra of WSOC}

Light absorption of aqueous extracts was measured with a TU-1900 UV/Vis-spectrometer (Persee, China). The aqueous method follows the details described by Hecobian et al. (2010). The following power law equation could characterize the light absorption spectra of the aqueous solutions:

$\operatorname{Abs}_{\lambda}=\mathrm{K} \cdot \lambda^{-\AA_{\mathrm{p}}}$

where $K$ is a constant, $\lambda$ is the wavelength and $\AA_{p}$ is the absorption Ångstrom exponent (AAE). AAE was calculated based on the linear regression fit of logarithms of $\mathrm{Abs}_{\lambda}$.

Mass Absorption Efficiency (MAE), a key parameter to describe the light absorption ability of chromophores, is the intensity of light absorbed per unit mass at a certain wavelength. Higher MAE value indicates stronger light absorption ability of chromophores, and the light absorption intensity is bigger in the case of the same mass. The MAE of WSOC was calculated as follows:

$\mathrm{MAE}_{365}=\frac{\mathrm{Abs}_{365}}{\mathrm{WSOC}}$

where $\mathrm{Abs}_{365}$ is the average value of optical absorption between 360 and $370 \mathrm{~nm}$ (See Formula S2), WSOC is the measured concentration of WSOC. The unit of $\mathrm{MAE}_{365}$ is $\mathrm{m}^{2} \mathrm{~g}^{-1}$.

\subsection{The extended aerosol inorganic model (E-AIM)}

E-AIM, developed by Simon Clegg and Anthony Wexler (Wexler and Clegg, 2002), is a thermodynamic model to calculate gas/aqueous/solid partitioning in aerosol systems. In this study, according to the actual atmospheric conditions and the types of inorganic ions contained in the samples, the E-AIM IV model was chosen. The inorganic element of Model IV is an equilibrium thermodynamic model of the system $\mathrm{H}^{+}-\mathrm{NH}_{4}^{+}-\mathrm{Na}^{+}-\mathrm{SO}_{4}{ }^{2-}-\mathrm{NO}_{3}{ }^{-}-\mathrm{Cl}^{-}-\mathrm{H}_{2} \mathrm{O}$ which is valid for temperatures near and/or below 263.15 up to $330 \mathrm{~K}$ and 
concentrations from infinite dilution to saturation with respect to the solid phases (Friese and Ebel, 2010). The input parameters of the model include ion concentrations, $\mathrm{RH}$, temperature, pressure and volume, dissociation options, gas and solid phase options, etc. And the output parameters include the moles and molarities of species in the gas, solid and aqueous phases, activity coefficient in the aqueous phase, volume and density of aqueous phase, etc.

\subsection{Potential source contribution function (PSCF)}

Potential source contribution function (PSCF) is a common method to identify regional sources and calculate the likelihood of identified sources. The PSCF values for the ijth grid cell were calculated as follows:

$\operatorname{PSCF}_{\mathrm{ij}}=\frac{\mathrm{m}_{\mathrm{ij}}}{\mathrm{n}_{\mathrm{ij}}}$

where $n_{i j}$ is the number of times that the trajectories passed through the cell $(i, j)$ and $m_{i j}$ is the number of "polluted" trajectories in the cell (i, j) (Zhang et al., 2013). To reduce the effect of small values of $n_{i j}$, the PSCF values were multiplied by a weighting function $\mathrm{W}_{\mathrm{ij}}$ :

$\mathrm{W}_{\mathrm{ij}}=\left\{\begin{array}{rr}1.00 & 3 \mathrm{n}_{\mathrm{Ave}}<\mathrm{n}_{\mathrm{ij}} \\ 0.70 & 1.5 \mathrm{n}_{\mathrm{Ave}}<\mathrm{n}_{\mathrm{ij}}<3 \mathrm{n}_{\mathrm{Ave}} \\ 0.42 & \mathrm{n}_{\mathrm{Ave}}<\mathrm{n}_{\mathrm{ij}}<1.5 \mathrm{n}_{\mathrm{Ave}} \\ 0.17 & 0<\mathrm{n}_{\mathrm{ij}}<\mathrm{n}_{\mathrm{Ave}}\end{array}\right\}$

\section{Results and discussion}

\subsection{General characteristics of $P M_{2.5}$}

The average $\mathrm{PM}_{2.5}$ concentration was $56.22 \pm 26.64 \mu \mathrm{g} \mathrm{m}^{-3}$ in this campaign at YRDNNR. The temporal variability of $\mathrm{PM}_{2.5}$, identified species in $\mathrm{PM}_{2.5}$ and meteorological parameters are shown in Fig. S1. Among all samples, $73.7 \%$ of the daily $\mathrm{PM}_{2.5}$ samples at YRDNNR had higher concentrations than $35 \mu^{-3} \mathrm{~m}^{-3}$, the recommended limit of daily $\mathrm{PM}_{2.5}$ concentration in A class areas according to the National Ambient Air Quality Standards in China (GB3095-2012). Table 1 shows the average concentrations of $\mathrm{PM}_{2.5}$ and identified species in $\mathrm{PM}_{2.5}$ and meteorological parameters in winter and summer. Compared with urban sites in the North China Plain (Gu et al., 2010; Wu et al., 2017; Zhou et al., 2012), the seasonal variation of $\mathrm{PM}_{2.5}$ at YRDNNR exhibited an opposite trend with higher concentrations in summer and lower

Table 1

Statistics of $\mathrm{PM}_{2.5}$ mass concentrations, water-soluble organic ions in $\mathrm{PM}_{2.5}$ and

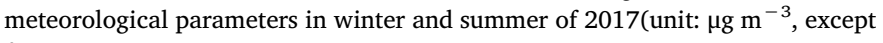
for OC/EC).

\begin{tabular}{lll}
\hline Species & Winter & Summer \\
\hline $\mathrm{PM}_{2.5}$ & $50.38 \pm 21.27$ & $63.15 \pm 25.35$ \\
$\mathrm{OC}$ & $5.14 \pm 2.54$ & $6.24 \pm 3.31$ \\
$\mathrm{EC}$ & $0.56 \pm 0.26$ & $0.47 \pm 0.18$ \\
$\mathrm{SOC}$ & $2.19 \pm 1.73$ & $3.71 \pm 2.50$ \\
$\mathrm{WSOC}$ & $3.23 \pm 1.75$ & $4.62 \pm 2.90$ \\
$\mathrm{OC}^{-} \mathrm{EC}$ & $9.71 \pm 2.79$ & $13.08 \pm 3.55$ \\
$\mathrm{Cl}^{-}$ & $1.38 \pm 0.96$ & $0.71 \pm 0.56$ \\
$\mathrm{NO}_{3}{ }^{-}$ & $8.50 \pm 6.28$ & $9.32 \pm 7.66$ \\
$\mathrm{SO}_{4}{ }^{-}$ & $3.83 \pm 2.58$ & $12.44 \pm 7.89$ \\
$\mathrm{NH}_{4}{ }^{+}$ & $4.28 \pm 3.28$ & $7.28 \pm 4.67$ \\
$\mathrm{Na}^{+}$ & $0.52 \pm 0.12$ & $0.44 \pm 0.11$ \\
$\mathrm{~K}^{+}$ & $0.38 \pm 0.25$ & $0.57 \pm 0.37$ \\
$\mathrm{Mg}^{2+}$ & $0.05 \pm 0.04$ & $0.02 \pm 0.02$ \\
$\mathrm{Ca}^{2+}$ & $0.43 \pm 0.22$ & $0.21 \pm 0.06$ \\
${\mathrm{Temperature}\left({ }^{\circ} \mathrm{C}\right)}_{\left.\mathrm{RH}^{+} \%\right)}$ & 5.9 & 27.1 \\
Wind speed $\left(\mathrm{m} \mathrm{s}^{-1}\right)$ & 66.8 & 75.3 \\
\hline
\end{tabular}

concentrations in winter. With fewer local emission sources at YRDNNR, different transportation modes of pollutants probably had a certain impact on the special seasonal trend. Fig. 1 shows the results of 72-h air mass back trajectories calculated by the NOAA HYSPLIT 4 trajectory model. From the figure, in winter, a large portion (55\%) (clusters 1, 2 and 4) of the air masses originated from Mongolia and Russia where the $\mathrm{PM}_{2.5}$ concentrations were very low (Yao et al., 2016). Moreover, the longer trajectories in winter implied the air masses moved faster which was beneficial to the dilution and diffusion of pollutants in the atmosphere. By contrast, in summer, a dominant amount (50\%) of the air masses was mainly from eastern Jiangsu province and the Yellow sea, passing through the cities of Zibo, Weifang and Linyi in Shandong province (cluster 3), which are all severe PM pollution regions (Luo et al., 2018; Wang et al., 2017; Xing et al., 2017). In addition, a considerable number of air masses (clusters 2 and 4) came from or passed through some heavily polluted cities in Shandong province such as Jinan, Zaozhuang and Taian (Liu et al., 2016; Wang et al., 2005; Zhang et al., 2018a). Most air masses moved slower in summer, and thus the pollutants readily accumulated.

The water-soluble inorganic ions were the most abundant constituents in $\mathrm{PM}_{2.5}$, accounting for $38 \%$ and $49 \%$ of the $\mathrm{PM}_{2.5}$ mass in winter and summer, respectively (Fig. 2). Secondary ionic aerosols (SNA) including $\mathrm{SO}_{4}{ }^{2-}, \mathrm{NO}_{3}{ }^{-}$and $\mathrm{NH}_{4}{ }^{+}$, were the dominant components with a total concentration of $16.61 \pm 11.93 \mu \mathrm{g} \mathrm{m}^{-3}$ and $29.37 \pm 17.83 \mu \mathrm{g} \mathrm{m}^{-3}$, occupying $86 \%$ and $95 \%$ of the measured water-soluble inorganic ions in winter and summer, respectively. From Table 1, the concentrations of $\mathrm{SO}_{4}{ }^{2-}$ and $\mathrm{NH}_{4}{ }^{+}$in summer were 1.7-3.2 times higher than those in winter. This was probably related to the transportation of air mass through heavy pollution area to the site and the ideal conditions (e.g., the higher temperature, $\mathrm{RH}$ and adequate sunshine) for the photochemical conversion reaction of $\mathrm{SO}_{2}$ to $\mathrm{SO}_{4}{ }^{2-}$ through both gaseous and aqueous phases in summer (Fugaś and Gentilizza, 1978; Galloway, 1989; Gorham et al., 1984). Another, in summer a considerable number of air masses originated from marine regions (Fig. 1), the increased $\mathrm{SO}_{4}{ }^{2-}$ concentrations could also likely be related to the phytoplankton activity (Barnes et al., 2006; Li et al., 2018). Although the levels of $\mathrm{NO}_{3}{ }^{-}$were comparable in winter and summer, the contributions of $\mathrm{NO}_{3}{ }^{-}$to the total amount of water-soluble inorganic ions in winter (44\%) was much higher than that in summer (30\%). This might be because $\mathrm{NO}_{3}{ }^{-}$is easier to retain in particulate phases at relatively low temperatures (winter). But in summer $\mathrm{NO}_{3}{ }^{-}$is more likely to form $\mathrm{HNO}_{3}$ and volatilizes into the gas phase (Stelson et al., 1979), although the air masses were from the relative clean area in winter to that in summer. $\mathrm{Cl}^{-}$could both come from coal consumption and sea salt. However, in this study $\mathrm{Cl}^{-}$showed a weak correlation with $\mathrm{Na}^{+}$in both seasons $\left(\mathrm{R}^{2} \leq 0.1\right)$, indicating $\mathrm{Cl}^{-}$might mainly be influenced by coal combustion at YRDNNR. In comparison, $\mathrm{Cl}^{-}$concentration in winter was substantially higher, which was probably because the abundant coal consumption for heating and the relatively low temperature was in favor of retaining $\mathrm{Cl}^{-}$in the particulate phase as well.

The carbonaceous aerosol constituted a considerable fraction of the fine particles, accounting for $11 \%$ of the total aerosol mass. OC was the dominant carbonaceous aerosol at YRDNNR, accounting for $92 \%$ of total carbonaceous matters during the sampling period. The concentrations of OC in summer was higher than that in winter. EC was a minor component of $\mathrm{PM}_{2.5}$, accounting for $8 \%$ of total carbonaceous matters during the sampling period, with a slightly higher concentration in winter compared with that in summer. The average OC/EC ratios were 9.71 and 13.08 in winter and summer, respectively, far higher than 2.0, indicating that probably SOC exists (Niu et al., 2013). Based on the EC-tracer method (Huang et al., 2012), the concentrations of SOC can be calculated:

$\mathrm{SOC}=\mathrm{OC}-\mathrm{POC}=\mathrm{OC}-\mathrm{EC} \times\left(\frac{\mathrm{OC}}{\mathrm{EC}}\right)_{\min }$ 

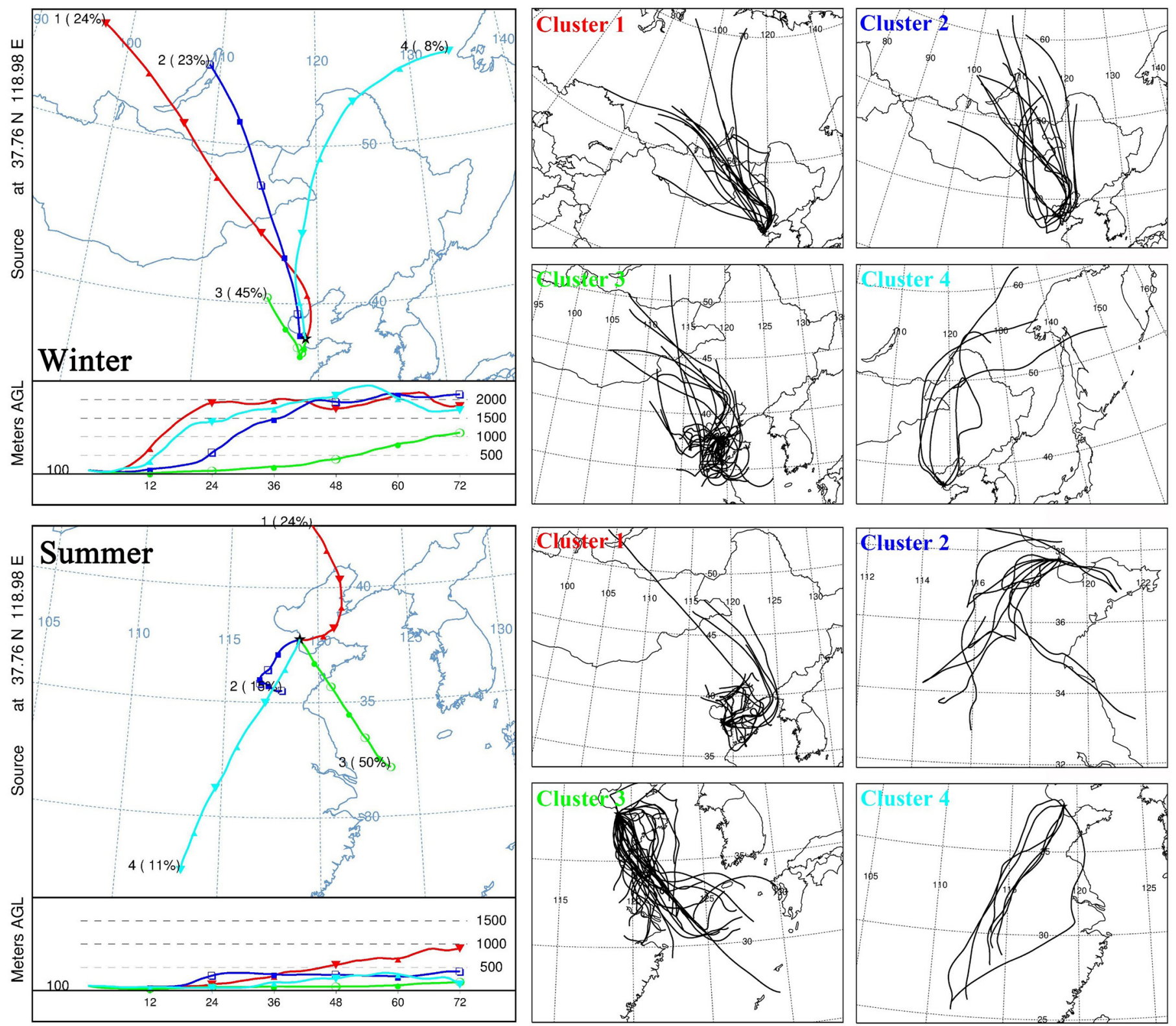

Fig. 1. Analytical results of the $72 \mathrm{~h}$ air mass back trajectories at $100 \mathrm{~m}$ elevation during the sampling period using NOAA HYSPLIT 4 trajectory model.

where POC is primary organic carbon and $(\mathrm{OC} / \mathrm{EC})_{\min }$ is the minimum OC/EC ratio in winter and summer respectively.

Normally, biomass burning and secondary formation could both contribute to the high ratio of OC/EC (Watson et al., 2001). A detailed inspection found that there was a good correlation between OC/EC and
SOC $\left(\mathrm{R}^{2}=0.60\right)$ while a quite weak correlation existed between OC/EC and $\mathrm{K}_{\mathrm{bb}}^{+}\left(\mathrm{R}^{2}=0.09\right)\left(\mathrm{K}_{\mathrm{bb}}^{+}: \mathrm{K}^{+}\right.$from biomass burning, which were estimated as reported by Yang et al. (2014) (See Supplement materials Formula S3-S7)), confirming that the high OC/EC at YRDNNR could be attributed to secondary formation. SOC comprised $43 \%$ and $60 \%$ of OC
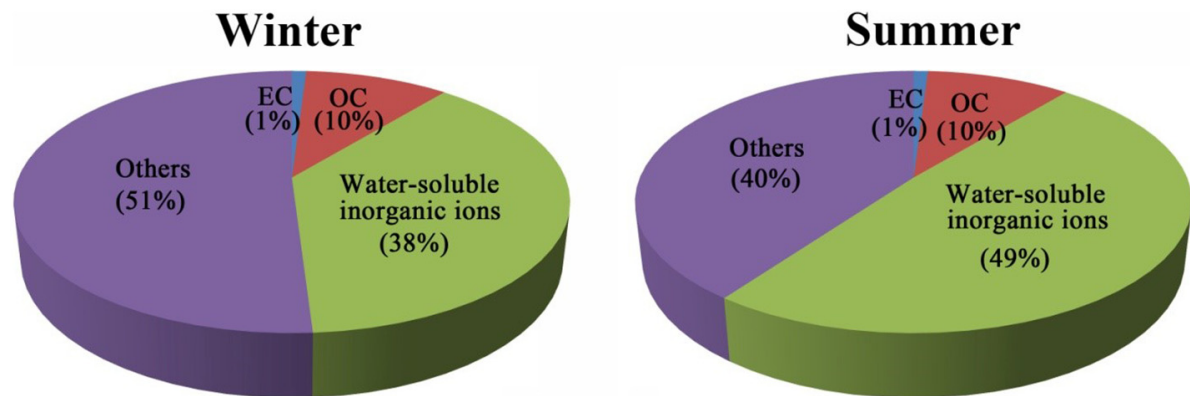

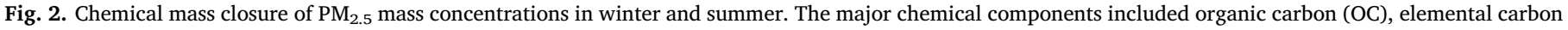
(EC), water-soluble inorganic ions and others unmeasured. 
Table 2

Concentrations of WSOC and WSOC/OC ratios at YRDNNR and other sites worldwide.

\begin{tabular}{|c|c|c|c|c|}
\hline Sampling site & Season & $\begin{array}{l}\text { WSOC } \\
\left(\mu \mathrm{g} \mathrm{m}^{-3}\right)\end{array}$ & $\begin{array}{l}\text { WSOC/OC } \\
(\%)\end{array}$ & Reference \\
\hline \multicolumn{5}{|c|}{ Background site } \\
\hline \multirow[t]{2}{*}{ YRDNNR } & Winter & 3.23 & 63 & This study \\
\hline & Summer & 4.62 & 74 & \\
\hline \multirow[t]{2}{*}{ Qinghai Lake } & Winter & 1.53 & 39 & Zhao et al. (2015) \\
\hline & Summer & 1.27 & 55 & \\
\hline \multirow[t]{2}{*}{ Texas, U.S } & Winter & 1.3 & 55 & $\begin{array}{l}\text { Barrett and Sheesley } \\
\text { (2014) }\end{array}$ \\
\hline & Summer & 2.0 & 66 & \\
\hline \multirow[t]{2}{*}{ Netherlands } & Winter & 1.3 & 62 & Dusek et al. (2017) \\
\hline & Summer & 0.73 & 73 & \\
\hline \multirow[t]{2}{*}{ Greece } & Winter & 0.7 & 39 & Taghvaee et al. (2019) \\
\hline & Summer & 1.4 & 70 & \\
\hline \multicolumn{5}{|c|}{ Rural/suburban sites } \\
\hline Beijing & Summer & 2.9 & 49 & Pathak et al. (2011) \\
\hline Guangzhou & Summer & 2.4 & 36 & \\
\hline Lanzhou & Summer & 4.3 & 29 & \\
\hline Shanghai & Summer & 2.9 & 46 & Feng et al. (2013) \\
\hline
\end{tabular}

in winter and summer, respectively, illustrating the more intense secondary formation in summer. The OC/EC ratios were much higher than those in the megacities sites of the North China Plain, such as Beijing (2.47) (He et al., 2001), Tianjin (3.00) (Gu et al., 2010) and Jinan (6.23) (Yang et al., 2012).

\subsection{Temporal variation and characteristics of WSOC}

\subsubsection{Temporal variations of WSOC}

Table 2 shows WSOC levels and WSOC/OC ratios at YRDNNR and other sites worldwide. As shown in the table, the average concentrations of WSOC were $3.23 \pm 1.75 \mu \mathrm{g} \mathrm{m}^{-3}$ and $4.62 \pm 2.90 \mu \mathrm{g} \mathrm{m}^{-3}$ in winter and summer, respectively, higher than those at a rural site in Beijing and at suburban sites near Shanghai and Guangzhou and Lanzhou. The four sampling sites mentioned above were in four major cities representing northern, eastern, southern and western China, respectively. Moreover, the levels of WSOC were far higher than those at background sites in China (Zhao et al., 2015) and other countries (Barrett and Sheesley, 2014; Dusek et al., 2017; Taghvaee et al., 2019). These indicated that WSOC pollution was serious at YRDNNR which might be attributed to the transportation of air masses from the oil fields in urban regions of Dongying and some heavy pollution areas in other cities (Fig. 3). WSOC was a major part of organic matter constituting about $66 \%$ of OC, $63 \%$ in winter and $74 \%$ in summer at YRDNNR. These were much higher than those at the background site in Qinghai Lake and the rural/suburban sites in Beijing, Shanghai, Guangzhou and Lanzhou in China. Besides, it was also higher than those at some background sites in other countries, such as Greece, Netherlands and Texas (Table 2). The pattern of WSOC in seasons was similar to that of $\mathrm{PM}_{2.5}$. This was different from those at the urban sites in China (Huang et al., 2012; Xiang et al., 2017). The higher WSOC concentration in summer was probably attributed to the increased secondary formation due to the favorable meteorological conditions. In addition, air mass transportation also probably played a significant role in elevating the WSOC level in summer due to most of them passing through the heavy pollution area (Fig. 3).

Fig. 3 shows the PSCF simulation results at YRDNNR. The air trajectories determined by PSCF model (Fig. 3(a) \& (d)) were similar to that using HYSPLIT (Fig. 1). In winter, the air masses mainly came from the northern regions of the sampling site while in summer, majority amounts of air masses were from southern regions of the sampling site. The concentrations of WSOC in clusters 1-4 were Cluster 1 $\left(4.18 \mu \mathrm{g} \mathrm{m}^{-3}\right)>$ Cluster $2 \quad\left(2.86 \mu \mathrm{g} \mathrm{m}^{-3}\right)>$ Cluster 4 $\left(2.52 \mu \mathrm{g} \mathrm{m}^{-3}\right)>$ Cluster $3\left(2.20 \mu \mathrm{g} \mathrm{m}^{-3}\right)$ in winter, and Cluster 2 $\left(7.68 \mu \mathrm{g} \mathrm{m}^{-3}\right)>$ Cluster $\quad 1 \quad\left(4.62 \mu \mathrm{g} \mathrm{m}^{-3}\right)>$ Cluster $\quad 3$ $\left(4.12 \mu \mathrm{g} \mathrm{m}^{-3}\right)>$ Cluster $4\left(3.38 \mu \mathrm{g} \mathrm{m}^{-3}\right)$ in summer. Fig. 3(a) and (b) show the likely source regions of WSOC in winter and summer. In winter, the potential source region of WSOC at YRDNNR was Shandong province including Dongying city and the inland cities in central Shandong province such as Weifang, Zibo, Jinan and Linyi. Shandong province has a high population density and a great gross domestic product (GDP) mainly driven by rapidly growing heavy industry, so it has been suffering severe particle pollution for a long time (Luo et al., 2018). In summer, in addition to the cities in Shandong province, WSOC could also come from eastern Jiangsu province where intensive power plants and fossil-fuel based industries are located (Li et al., 2015). Additionally, the eastern region of Henan province where particle pollution was severe (Jiang et al., 2017; Jiang et al., 2018) could be another potential region of WSOC at YRDNNR. Since the clusters 2, 3 and 4 in winter and clusters 3 and 4 in summer all passed through the Bohai sea or the Yellow sea, the two seas might be identified as likely marine sources of WSOC. There were some big ports like Qingdao ports along the coast and the exhaust of ships might lead to the increase of WSOC in particular phase. The likely source regions identified by PSCF showed good agreement with the results of cluster analysis (Fig. 3), suggesting that regional transportation could be one of the important reasons for the seasonal differences of WSOC at YRDNNR.

\subsubsection{Primary and secondary formation}

3.2.2.1. Correlations between WSOC and OC and EC. In this study, a strong correlation was found between WSOC and $\mathrm{OC}\left(\mathrm{R}^{2}>0.85\right)$, while the correlations between WSOC and EC were weak $\left(\mathrm{R}^{2}=0.36\right)$. Besides the temporal variations of WSOC and OC were comparatively consistent while the temporal variations of WSOC and EC were inconsistent (Fig. S1), suggesting that WSOC was more related to secondary formation at YRDNNR. The ratio of WSOC to OC was 0.74 in summer, a little higher than that in winter (0.63). There was a stronger correlation between WSOC and OC $\left(\mathrm{R}^{2}=0.96\right)$ and a weaker correlation of WSOC and EC was relatively weak $\left(\mathrm{R}^{2}=0.51\right)$ in summer than those in winter $\left(R^{2}=0.76\right.$ and $\left.R^{2}=0.56\right)$. Therefore, the higher contribution of WSOC to OC in summer was presumably attributed to photochemical processes that occur under the summer conditions of higher RH, ambient temperature and sunlight (Jaffrezo et al., 2005; Kondo et al., 2007; Park and Cho, 2011).

3.2.2.2. Correlations of WSOC and inorganic ions. Correlations of WSOC with secondary inorganic ions $\left(\mathrm{SO}_{4}{ }^{2-}, \mathrm{NO}_{3}{ }^{-}\right.$and $\left.\mathrm{NH}_{4}{ }^{+}\right), \mathrm{Cl}^{-}$, biomass burning tracer $\mathrm{K}_{\mathrm{bb}}^{+}$were also investigated at YRDNNR (Fig. 4). WSOC correlated well with $\mathrm{SO}_{4}{ }^{2-}$ in winter $\left(\mathrm{R}^{2}=0.81\right)$ and slightly lower in summer $\left(\mathrm{R}^{2}=0.74\right)$, indicating that they may have similar sources or formation pathways. The major formation process of $\mathrm{SO}_{4}{ }^{2-}$ has been suggested to be aqueous reaction (Wang et al., 2012; Yao et al., 2002). Therefore, the strong correlation between WSOC and $\mathrm{SO}_{4}{ }^{2-}$ indicated that aqueous reaction was probably an important formation pathway of WSOC. The correlation between WSOC and $\mathrm{NO}_{3}{ }^{-}$exhibited an obvious seasonal variation with a better correlation in winter than that in summer. The formation of $\mathrm{NO}_{3}{ }^{-}$is usually thought to be associated with secondary reactions in the atmosphere. Besides, Hodas et al. (2014) has suggested that particulate $\mathrm{NO}_{3}{ }^{-}$is one of the main drivers of aerosol liquid water (ALW) which has an important impact on the formation and partitioning of WSOC (see Section 3.2.2.3). The good correlation between WSOC and $\mathrm{NO}_{3}{ }^{-}$in winter could suggest a similar formation mechanism between them. In summer, the dissociation of $\mathrm{NH}_{4} \mathrm{NO}_{3}$ was notable at relatively higher temperatures. Besides, sampling artifacts for $\mathrm{NO}_{3}{ }^{-}$and the other secondary formation pathways of WSOC (e.g. oxalate formation path) could all lead to a lower correlation between WSOC and $\mathrm{NO}_{3}{ }^{-}$. The correlation pattern between WSOC and $\mathrm{NH}_{4}{ }^{+}$in different seasons was similar to that of WSOC and $\mathrm{NO}_{3}{ }^{-}$.

There was a strong correlation between WSOC and $\mathrm{K}_{\mathrm{bb}}^{+}\left(\mathrm{R}^{2} \geq 0.7\right)$, 

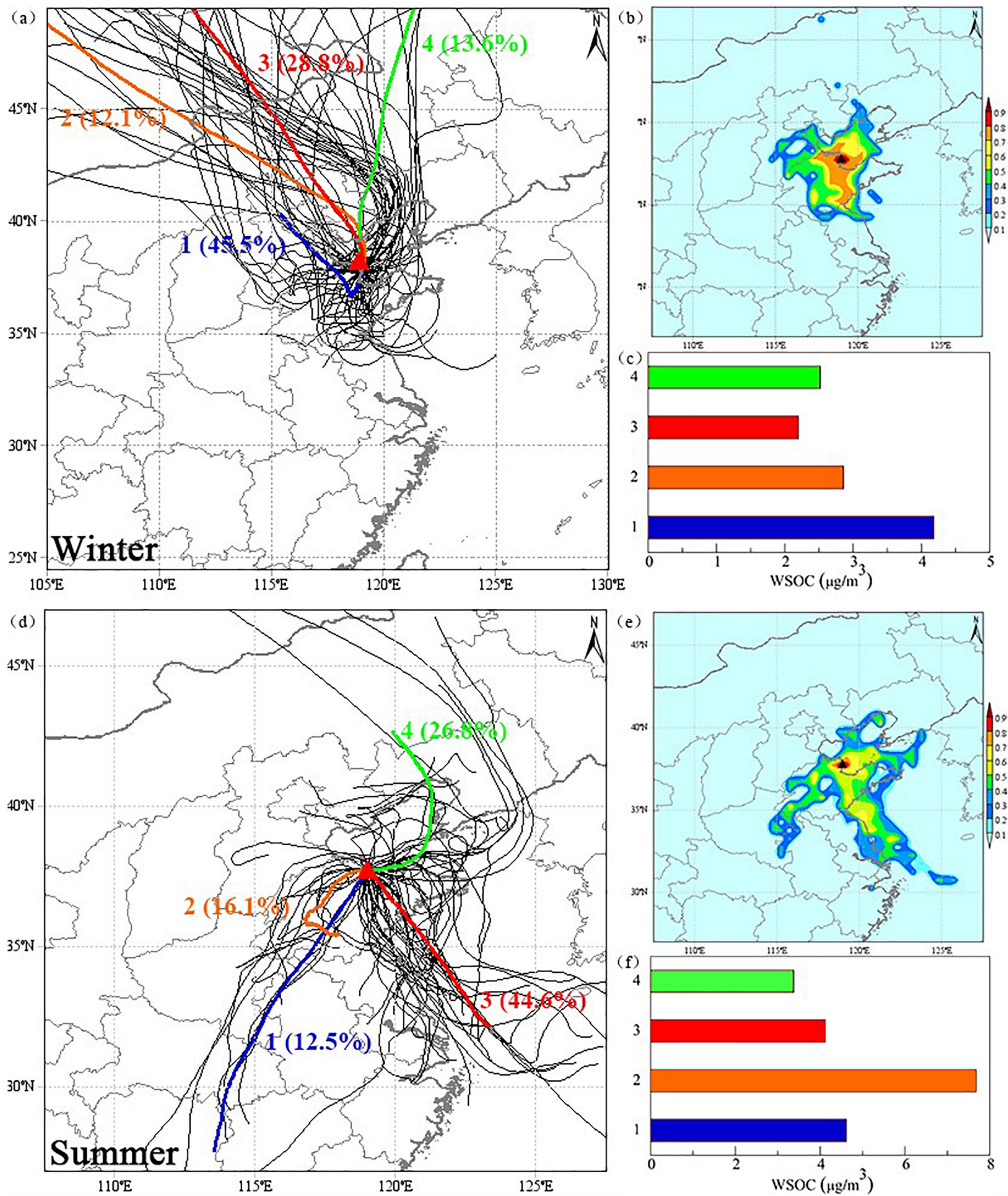

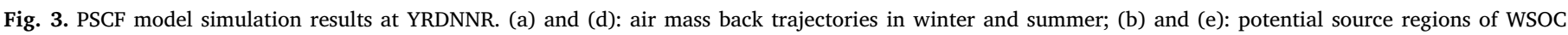
identified by PSCF values in winter and summer; (c) and (f): WSOC concentrations of each cluster identified by PSCF model in winter and summer. 


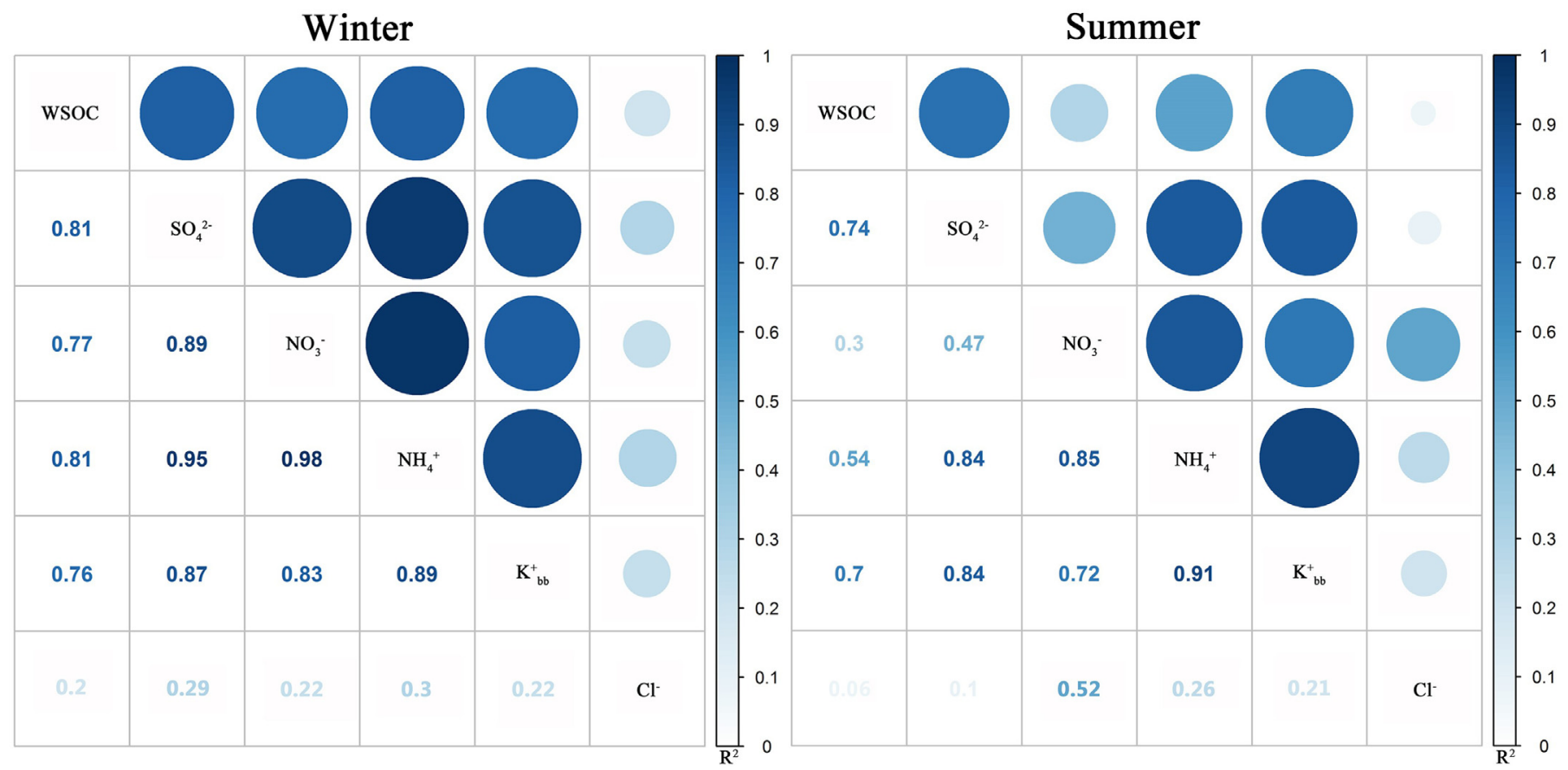

Fig. 4. Image plots showing the cross-correlation coefficients $\left(\mathrm{R}^{2}\right.$ ) between WSOC, $\mathrm{SO}_{4}{ }^{2-}, \mathrm{NO}_{3}{ }^{-}, \mathrm{NH}_{4}{ }^{+}$and $\mathrm{K}_{\mathrm{bb}}^{+}$in winter and summer (colored and sized by $\mathrm{R}^{2}$ : the deeper color and larger size represent the higher $\mathrm{R}^{2}$ ).

indicating that biomass burning was an important source of WSOC. This meant that part of WSOC was thought to be from primary biomass burning emission and/or the chemical conversion of precursors from the biomass burning (e.g. levoglucosan, phenolic compounds and so on) in the atmosphere (Sun et al., 2010; Yu et al., 2014; Zhao et al., 2014). The correlations between WSOC and $\mathrm{K}_{\mathrm{bb}}^{+}$did not show an obvious seasonal variation at YRDNNR. The correlations between WSOC and $\mathrm{Cl}^{-}$were very weak in both seasons (winter: $\mathrm{R}^{2}=0.2$, summer: $\mathrm{R}^{2}=0.06$ ), indicating WSOC was less related to coal combustion.

3.2.2.3. Relationship between WSOC and SOC. A strong correlation was seen between WSOC and SOC $\left(\mathrm{R}^{2}=0.83\right)$ during the whole campaign at YRDNNR (Figs. 5 and 6), and in Fig. S1, the consistent temporal variations of WSOC and SOC were obviously found, further confirming that a comparable amount of WSOC was from secondary formation. In summer, there was a relatively high correlation between WSOC and SOC $\left(R^{2}=0.92\right)$ compared with that in winter $\left(R^{2}=0.62\right)$, suggesting the active photochemical reactions probably have a significant contribution to WSOC (Sullivan and Weber, 2006). The relatively weak correlation in winter probably indicates more influences from primary sources.

In order to further explore the secondary formation of WSOC, ALW and particle acidity were investigated, as described below.

3.2.2.3.1. Aerosol liquid water ( $A L W)$. ALW is ubiquitous and important in the atmosphere. It could affect the partitioning of gasphase WSOC to particle-phase. Moreover, a substantial body of research suggest that ALW plays a critical role in SOA formation by affecting the partitioning of organic matter in the condensed phase and providing the reaction medium and surface area for aqueous reactions (Blando and Turpin, 2000; Ervens et al., 2011; Hodas et al., 2014; Lim et al., 2010). Here ALW was estimated using a thermodynamic model (E-AIM IV, http://www.aim.env.uea.ac.uk/aim/aim.php). $\mathrm{SO}_{4}{ }^{2-}, \mathrm{NO}_{3}{ }^{-}, \mathrm{Cl}^{-}$, $\mathrm{NH}_{4}{ }^{+}$and $\mathrm{Na}^{+}$were input into the model. The output parameter of the model is $\mathrm{H}_{2} \mathrm{O}$ (aq), which refers to the mass of liquid water contained in aerosols in $1 \mathrm{~m}^{3}$ of air. Therefore, the concentration of ALW could be obtained by unit conversion of the output result of $\mathrm{H}_{2} \mathrm{O}$ (aq) $\left(\mu \mathrm{g} \mathrm{m}^{-3}\right)$. And the average concentrations of ALW were $19.53 \pm 25.52 \mathrm{\mu g} \mathrm{m}^{-3}$ in winter and $49.18 \pm 44.68 \mu \mathrm{g} \mathrm{m}^{-3}$ in summer.

From Fig. 5(a), it can be found that the concentrations of WSOC and SOC were higher with higher concentration of ALW, indicating that ALW could promote WSOC formation in the measurement. This tendency was more obvious (Fig. 5(b)) in winter than that in summer (Fig. 5(c)). In summer, a few samples did not conform to the pattern above. To further investigate these special samples, the other factors, e.g., $\mathrm{PM}_{2.5}$ concentrations, wind speeds and temperatures were inspected (Fig. 5(d)-(f)). In Fig. 5(c), the samples on the nights of June 13th, 20th, 25th and 28th (red triangles) had lower WSOC and SOC concentrations at relatively high ALW. This might be attributed to the lower concentrations of $\mathrm{PM}_{2.5}$ of these samples. Besides, from Fig. 5(f), the temperatures were much lower during these periods so that the photochemical reactions could be relatively weak. These all could lead to less secondary WSOC even under the higher ALW conditions. The samples taken during the day on June 15th, 16th and 17th (blue triangles) had low ALW levels but high concentrations of both WSOC and SOC. This was probably due to relatively high $\mathrm{PM}_{2.5}$ concentrations in these periods (Fig. 5(d)). In addition, the wind speeds were lower (Fig. 5(e)) and the temperatures were much higher (Fig. 5(f)) which could be favorable for the accumulation of WSOC and the secondary formation. The ALW concentration in summer was about 2.5 times that in winter, which meant that the ALW was relatively sufficient for the secondary formation and the dissolution of WSOC. As discussed above, it is possible that other meteorological factors like wind speed, light intensity and temperature might greatly influence the secondary formation of WSOC rather than the ALW under the ALW-rich conditions (the concentration of ALW was high enough). However, the ALW level could play a very important role in the secondary WSOC under the ALW-poor conditions like that in winter.

3.2.2.3.2. Particle acidity. In the atmosphere, both SOA formation and POA oxidation are influenced by particle acidity via heterogeneous reaction processes (Kawamura et al., 2010; Pathak et al., 2011; Surratt et al., 2007; Zhang et al., 2007). SOA and oxygenated POA are thought to compose the major part of WSOC (Kondo et al., 2007; Pathak et al., 2011; Zhang et al., 2007). Therefore, the correlation between WSOC and particle acidity is discussed in this study. The particle acidity was represented with in-situ $\mathrm{pH}$ that was calculated as below: 

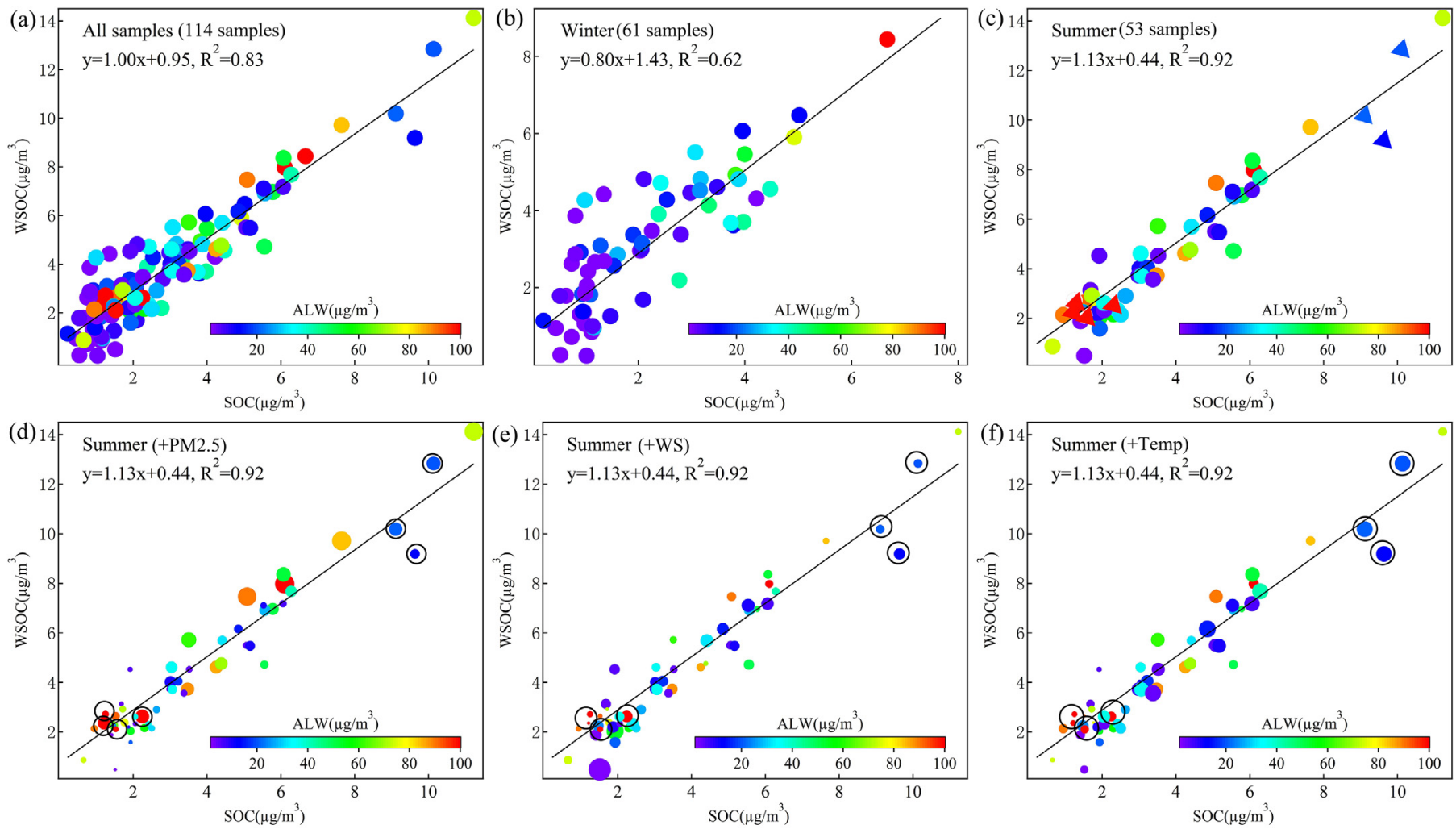

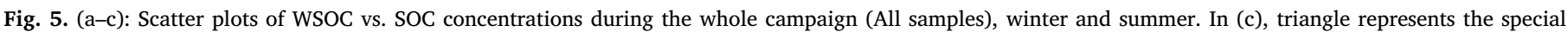

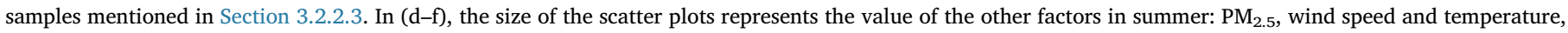

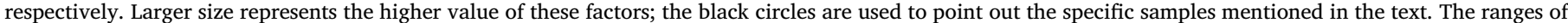
these factors: $\mathrm{PM}_{2.5}: 23.3-134.1 \mu \mathrm{g} \mathrm{m}^{-3}$; wind speed: $0.2-7.3 \mathrm{~m} \mathrm{~s}^{-1}$; temperature: $19.1{ }^{\circ} \mathrm{C}-33.6{ }^{\circ} \mathrm{C}$.

in-situ $\mathrm{pH}=-\log \left[\gamma \times\left[\mathrm{H}^{+}\right] /\left(\mathrm{V}_{\mathrm{aq}} / 1000\right)\right]$

where $\gamma$ is the activity coefficient of $\mathrm{H}^{+},\left[\mathrm{H}^{+}\right]$is the mole number of $\mathrm{H}^{+}$and $\mathrm{V}_{\mathrm{aq}}$ is the volume of aqueous phase $\left(\mathrm{cm}^{3}\right) \cdot \gamma,\left[\mathrm{H}^{+}\right]$and $\mathrm{V}_{\mathrm{aq}}$ were calculated with the E-AIM IV model (http://www.aim.env.uea.ac.uk/ aim/aim.php).

The in-situ pH was 5.11 in winter and 4.96 in summer at YRDNNR. Fig. 6(a)-(c) show that both WSOC and SOC varied along with in-situ $\mathrm{pH}$. Both species increase with the decrease of $\mathrm{pH}$, indicating more secondary WSOC formation with the increase of acidity in particles. This is consistent with the laboratory studies where more SOA was produced under higher acidity conditions (Jang et al., 2002; Surratt et al., 2007). In field research in Tokyo, Kondo et al., (2007) also found that there was a $20 \%$ enhancement of OOA in acidic samples compared with neutralized samples, suggesting acidity plays a significant role in the formation of SOA. From Fig. 6(b), there were a few samples in which WSOC did not increase along with the decrease of the in-situ pH. In order to explain these special samples, three other factors, including $\mathrm{PM}_{2.5}$ concentrations, wind speeds and temperatures, were investigated (Fig. 6(d)-(f)). The samples on February 21th daytime, March 5th daytime and 6th night-time (Fig. 6(b) triangles) had lower WSOC and SOC concentrations and lower in-situ pH. The lower WSOC and SOC could be due to the lower $\mathrm{PM}_{2.5}$ concentrations (Fig. 6(d)). Fig. 6(e) and (f) show that the meteorological conditions (the larger wind speeds and lower temperatures) during February 21th daytime, March 5th daytime and 6th night-time could also be responsible for the lower secondary formation and accumulation of WSOC in winter at YRDNNR.

\subsubsection{Source apportionment of WSOC}

Source apportionment of WSOC was performed in winter and summer, respectively, using the Positive Matrix Factorization (PMF) 5.0 model. Descriptions of PMF model were shown in supplement materials. WSOC, OC, EC, $\mathrm{Cl}^{-}, \mathrm{SO}_{4}{ }^{2-}, \mathrm{NO}_{3}{ }^{-}, \mathrm{NH}_{4}{ }^{+}, \mathrm{K}_{\mathrm{bb}}^{+}, \mathrm{Na}^{+}, \mathrm{Mg}^{2+}$ and $\mathrm{Ca}^{2+}$ were input into the source apportionment model. In this study, we have tested from three to seven factors in the PMF model. Then, PMF was run several times with different Fpeak values to determine the range within which the objective function $Q$ values remains relatively constant (Fig. S2). In the five-factor result, a value of Fpeak $=-0.1$ provided the most physically reasonable source profiles. Species with a number of scaled residuals above 4 have peak concentrations that were not fit by PMF: $\mathrm{EC}$ and $\mathrm{Cl}^{-}$in winter, and $\mathrm{Cl}^{-}, \mathrm{K}_{\mathrm{bb}}^{+}$ and $\mathrm{Ca}^{2+}$ in summer. The category for these species was set to "Weak". There were good correlations $\left(\mathrm{R}^{2}>0.85\right)$ between simulated values from PMF model and the input data of each species. In addition, results of error estimation (Table S1-S5) also suggested the simulation was stable and reliable. Five factors were obtained and the source profiles are illustrated in Fig. 7.

Factor 1 , characterized by high loads of $\mathrm{EC}, \mathrm{Cl}^{-}, \mathrm{Na}^{+}$and $\mathrm{Ca}^{2+}$, was identified as mixed primary sources. As the results of PSCF shown (see Section 3.2.1), the Yellow sea and the Bohai sea were the potential source regions of WSOC, besides, nearly $46.1 \% \mathrm{Cl}^{-}$and $28.4 \% \mathrm{Na}^{+}$ were found in this factor, therefore, sea salt was one of the primary sources in this factor. In addition, high loads of $\mathrm{EC}, \mathrm{Cl}^{-}$and $\mathrm{Ca}^{2+}$ indicated fossil fuel combustion and soil dust were also included in factor 1. Factor 2 was characterized by a high load of $\mathrm{K}_{\mathrm{bb}}^{+}$and a medium load of OC. Thus, factor 2 was identified as biomass burning. Although biomass burning was a combination of both primary and secondary sources of WSOC, in this study factor 2 was regarded as a primary source due to the relatively high loads of EC, $\mathrm{Na}^{+}$and $\mathrm{Ca}^{2+}$. Thus, the contribution of factor 2 could be regarded as the maximum contribution from the biomass burning as a primary source of WSOC. Factor 3 had a high load of $\mathrm{SO}_{4}{ }^{2-}$ and medium loads of $\mathrm{NO}_{3}{ }^{-}$and $\mathrm{NH}_{4}{ }^{+}$, therefore, it was identified as the sulfate-based source. $>60 \%$ of $\mathrm{NO}_{3}{ }^{-}$was found in factor 4 , and the loads of $\mathrm{SO}_{4}{ }^{2-}$ and $\mathrm{NH}_{4}{ }^{+}$could also be as high as 

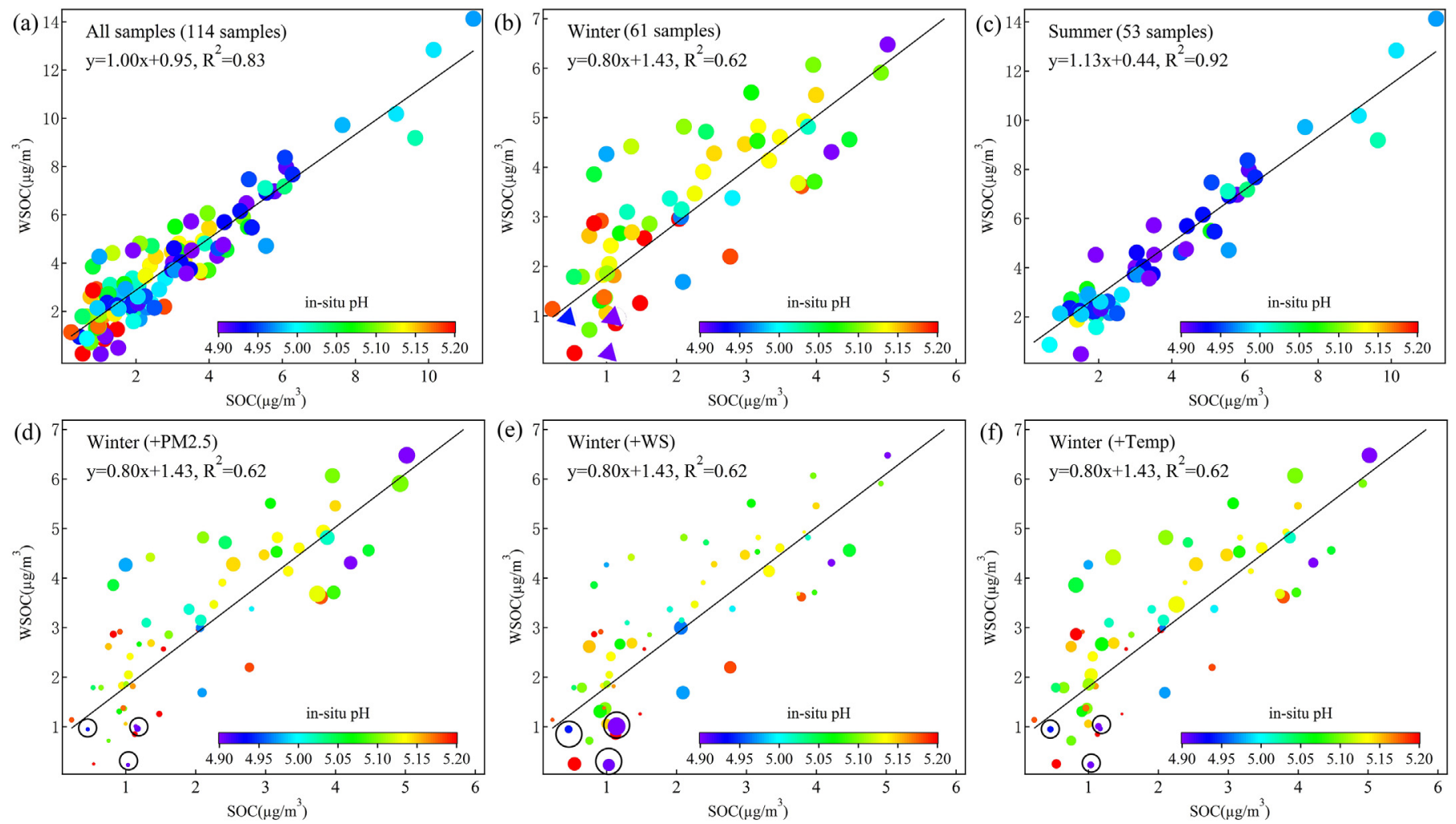

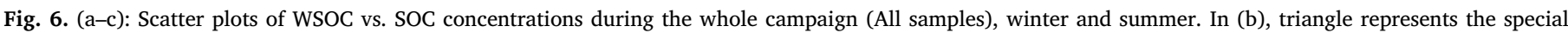

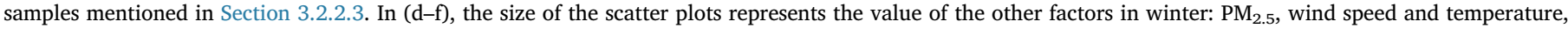

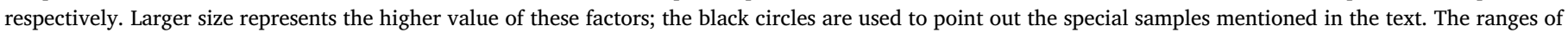
these factors: $\mathrm{PM}_{2.5}: 14.6-99.4 \mu \mathrm{g} \mathrm{m}^{-3}$; wind speed: $0.8-6.8 \mathrm{~m} \mathrm{~s}^{-1}$; temperature: $-3{ }^{\circ} \mathrm{C}-15.5{ }^{\circ} \mathrm{C}$.

$25.8 \%$ and $59.3 \%$, indicating this factor might be associated with nitrate-based source. Factor 5 was characterized by a high level of OC and medium level of $\mathrm{SO}_{4}{ }^{2-}, \mathrm{NO}_{3}{ }^{-}$and $\mathrm{K}_{\mathrm{bb}}^{+}$, thus was attributed to mixed organic formation. For instance, oxalate-path formation in the aqueous phase has been suggested to be associated with the formation of WSOC (Huang et al., 2006; Yao et al., 2002). Meanwhile, other secondary formation pathways such as SOA from terpene, pinonic acid and so on might also be identified as sources of WSOC (Feng et al., 2013). Thus, factor 5 might be representative of the secondary sources of WSOC.

Table 3 shows seasonal contributions of each identified source. Factors 1 and 2 represented the primary characteristics of WSOC while factors 3, 4 and 5 were considered as the secondary sources of WSOC in this study. The secondary formation contributed $59.9 \%$ and $77.9 \%$ of WSOC in winter and summer, indicating that WSOC was mainly from secondary formation at YRDNNR. The secondary formation proportion in summer was higher than that in winter. This was consistent with the better correlation between WSOC and SOC in summer (Figs. 5 and 6)
Table 3

Seasonal contributions of each source of WSOC (unit: \%).

\begin{tabular}{llll}
\hline Factor & Source & Winter & Summer \\
\hline 1 & Mixed primary sources & 8.5 & 2.0 \\
2 & Biomass burning & 31.6 & 20.1 \\
3 & Sulfate-based source & 5.9 & 7.2 \\
4 & Nitrate-based source & 19.1 & 12.3 \\
5 & Mixed organic formation & 34.9 & 58.4 \\
\hline
\end{tabular}

and higher ALW and particle acidity, which favor WSOC formation in this season (See Section 3.2.2.3), especially the aqueous phase formation. In contrast, the contributions of primary sources to WSOC were more in winter than summer with a factor of $\sim 2$. Among all these primary sources, biomass burning was predominant and contributed $31.6 \%$ to WSOC in winter that could be due to the frequent biomass burning in northern Chinese villages for heating in the cold season.

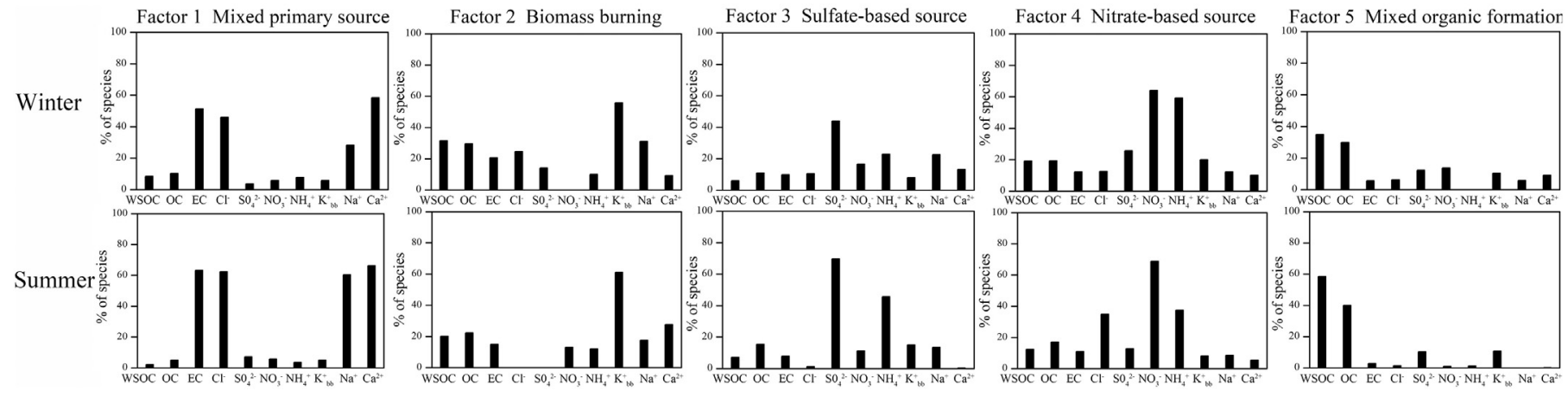

Fig. 7. Composition profiles (\% of each species) simulated by the PMF model. 
Among the three identified secondary sources of WSOC, the contribution of the sulfate-based source was lower compared with other studies (Du et al., 2014a; Feng et al., 2013). This might be attributed to very low concentrations of $\mathrm{SO}_{2}$ with an average of $5 \pm 5 \mathrm{ppb}$ and $2 \pm 3 \mathrm{ppb}$ in winter and summer, respectively, at YRDNNR (unpublished results). $\mathrm{SO}_{2}$, the precursor of $\mathrm{SO}_{4}{ }^{2-}$, mainly comes from the burning of fossil fuels. Compared to other urban sites, YRDNNR lacks direct emission sources of $\mathrm{SO}_{2}$, which may be not favorable for the formation of organic sulfate compounds like organosulfates. The higher contribution of the nitrate-based source in winter was consistent with the higher proportion of nitrate and stronger correlation between WSOC and nitrate in this season. $\mathrm{NO}_{3}{ }^{-}$is one of the main drivers of ALW which affects the formation and partition of WSOC species in particulate phase (Hodas et al., 2014; Pathak et al., 2011). $\mathrm{NO}_{3}{ }^{-}$is also involved with the aqueous formation of nitrogen-containing organics which was an important formation route of WSOC (Hodas et al., 2014). $\mathrm{Cl}^{-}$had a nearly $35 \%$ load in factor 4 in summer, because $\mathrm{Cl}^{-}$and $\mathrm{NO}_{3}{ }^{-}$were more likely to resolve at a relatively high temperature in this season. The higher load of $\mathrm{Cl}^{-}$in this factor was corresponding with the better correlation between $\mathrm{NO}_{3}{ }^{-}$and $\mathrm{Cl}^{-}$in summer (Fig. 4). In addition to the two secondary formation pathways mentioned above, the mixed organic formation sources, that is, some other aqueous reactions that were not specifically identified by PMF in this study, e.g., oxalate associated pathways and other acid catalysis reactions, was considered to have a significant contribution to WSOC as shown in factor 5 (Du et al., 2014a; Pathak et al., 2011). Compared with winter, the favorable meteorological condition and higher level of ALW and acidity could both lead to the higher contribution of mixed secondary formation in summer (Fig. 7).

\subsubsection{Light absorption characteristics of WSOC}

The wavelength dependence of light absorption from the aqueous extraction was investigated by the AAE $(310-400 \mathrm{~nm}$ ) (Kirillova et al., 2014). AAE values varied depending on sources of particle. Previous work has found that the AAE of fresh soot is about 1 (Bond, 2001; Kirchstetter et al., 2004) whereas the AAE of organic matter in particles (i.e., $\mathrm{BrC}$ ) is within the range from 2 to 4 (Bergstrom et al., 2007; Kirchstetter et al., 2004; Yang et al., 2009). The research by Bones et al. (2010) suggested that AAE for aqueous extractions of fresh SOA was close to 7 and the AAE value for aqueous extracts of aged SOA was around 4.7. The extraction method has an important impact on the AAE value. Many studies have reported that aqueous extracts of aerosols were likely to have higher AAE compared with other organic extracts (Hecobian et al., 2010; Hoffer et al., 2006; Liu et al., 2013). In this study, as WSOC was extracted using the same method, the difference of AAE values between winter and summer could suggest the discrepancies of components of WSOC. In winter, the AAE ranged between 4.3 and 9.92 with an average of 6.88 which was close to 7, the AAE for aqueous extractions of fresh SOA. However, in summer, the AAE averaged 9.15 and varied between 6.63 and 12.07. Chen and Bond (2010) have found that water extracts of aerosols from wood burning like oak and pine might have higher AAEs, ranging from 8.8-17.8. Therefore, the samples with higher AAE values might contain aerosols from wood burning.

Absorption averaged between 360 and $370 \mathrm{~nm}\left(\mathrm{Abs}_{365}\right)$ was used as an indicator of the light absorption property of water-soluble organic species (i.e., brown carbon) (Du et al., 2014b). The average $\mathrm{Abs}_{365}$ of WSOC was $3.60 \mathrm{Mm}^{-1}$ in winter and $2.41 \mathrm{Mm}^{-1}$ in summer. High correlation was found between $\mathrm{Abs}_{365}$ and WSOC $\left(\mathrm{R}^{2}>0.75\right)$ in both seasons, indicating WSOC and water-soluble brown carbon might have the similar sources at YRDNNR. In winter, biomass burning was likely to be a source of water-soluble brown carbon, which is strongly supported by the good correlation between $\mathrm{Abs}_{365}$ and $\mathrm{K}_{\mathrm{bb}}^{+}\left(\mathrm{R}^{2}=0.55\right)$. However, in summer, the correlation of $\mathrm{Abs}_{365} \mathrm{vs}$. $\mathrm{K}_{\mathrm{bb}}^{+}$and $\mathrm{EC}$ were poor $\left(\mathrm{R}^{2} \leq 0.30\right)$, indicating that secondary photochemical processes might be a main source of water-soluble brown carbon.
The light absorption ability of WSOC was characterized by MAE calculated using Formula 2. The average $\mathrm{MAE}_{365}$ in winter was $1.32 \mathrm{~m}^{2} \mathrm{~g}^{-1}$ and $0.38 \mathrm{~m}^{2} \mathrm{~g}^{-1}$ in summer. Both the values of $\mathrm{Abs}_{365}$ and $\mathrm{MAE}_{365}$ were higher in winter than those in summer indicating WSOC had stronger light absorbability in winter. And this result was corresponding to the higher AAE in summer than in winter, because the larger AAE value indicated the lower absorptive ability. The MAE 365 at YRDNNR was similar to the values observed in Beijing (winter: $1.26 \mathrm{~m}^{2} \mathrm{~g}^{-1}$; summer: $0.51 \mathrm{~m}^{2} \mathrm{~g}^{-1}$, in the North China Plain) (Du et al., 2014b) and central Tibetan Plateau (summer: $0.38 \mathrm{~m}^{2} \mathrm{~g}^{-1}$, background site in China) (Zhang et al., 2017b), but higher than that at a remote site in Indian Ocean (winter: $0.45 \mathrm{~m}^{2} \mathrm{~g}^{-1}$ ) (Srinivas and Sarin, 2013), indicating the light absorbability of WSOC at YRDNNR was much stronger, and WSOC would have the greater influence on the radiation forcing in this region with the same mass concentration.

The relative contribution of radiative adsorption of WSOC to EC was calculated to estimate the impact of WSOC on climate warming effect (Kirillova et al., 2014). The detailed process was shown in Supplement materials. The fraction of solar energy absorbed by WSOC to EC was $1 \%$ $-10 \%$ in the full solar spectrum $(300 \mathrm{~nm}-2500 \mathrm{~nm})$ during this campaign, which was similar with the range in Korea (Kirillova et al., 2014). And the average ratios in winter and summer were $2 \%$ and $1 \%$, respectively. In addition, the ratio of solar energy absorbed by WSOC to EC was also estimated in the ultraviolet region of the solar spectrum $(300 \mathrm{~nm}-400 \mathrm{~nm})$, and the average values were $11 \%$ and $6 \%$ in winter and summer, respectively. The much higher ratios indicated the stronger absorption effect and ability of WSOC in the UV region.

\section{Conclusions}

In this study, a comprehensive investigation of $\mathrm{PM}_{2.5}$ and species in $\mathrm{PM}_{2.5}$ was carried out in winter and summer at YRDNNR. WSOC averaged $3.86 \pm 2.44 \mu \mathrm{g} \mathrm{m}^{-3}$, accounting for $66 \%$ OC at the site. The results from PSCF model suggested that the cities in Shandong province, eastern Jiangsu province and northern Henan province were the potential source regions of WSOC. WSOC was closely related to secondary formation at YRDNNR. In addition, the secondary formation process of WSOC could be promoted by high level of ALW and particle acidity. Sources apportionment of WSOC by PMF model indicated that secondary formation was the main source, especially in summer. In comparison, primary sources contributed an average of $31.1 \%$ of WSOC during the whole measurement period, with a dominant contribution from biomass burning. The AAE of WSOC was 6.88 and 9.15 in winter and summer, respectively. The $\mathrm{MAE}_{365}$ in winter $\left(1.32 \mathrm{~m}^{2} \mathrm{~g}^{-1}\right)$ was higher than that in summer $\left(0.38 \mathrm{~m}^{2} \mathrm{~g}^{-1}\right)$, indicating the stronger light absorption ability of WSOC in winter. The direct light absorptive properties of WSOC were found to range $1-10 \%$ relative to that of the main light absorptive aerosol component, EC.

\section{Acknowledgements}

This work was supported by the National Natural Science Foundation of China (Grant Nos. 21507070, 41675118 and 91544213), Key Laboratory of Photochemical Conversion and Optoelectronic Materials, TIPC, CAS. The authors thank Dr. Pamela Holt for proofreading the manuscript.

\section{Appendix A. Supplementary data}

Supplementary data to this article can be found online at https:// doi.org/10.1016/j.atmosres.2019.104668.

\section{References}

Anderson, C., Dibb, J.E., Griffin, R.J., Bergin, M.H., 2008. Simultaneous measurements of particulate and gas-phase water-soluble organic carbon concentrations at remote and 
urban-influenced locations. GeoRL 35.

Asa-Awuku, A., Engelhart, G.J., Lee, B.H., Pandis, S.N., Nenes, A., 2009. Relating CCN activity, volatility, and droplet growth kinetics of $\beta$-caryophyllene secondary organic aerosol. Atmos. Chem. Phys. 9, 795-812.

Baduel, C., Voisin, D., Jaffrezo, J.L., 2010. Seasonal variations of concentrations and optical properties of water soluble HULIS collected in urban environments. Atmos. Chem. Phys. 10, 4085-4095.

Barnes, I., Hjorth, J., Mihalapoulos, N., 2006. Dimethyl sulfide and dimethyl sulfoxide and their oxidation in the atmosphere. Chem. Rev. 106, 940-975.

Barrett, T.E., Sheesley, R.J., 2014. Urban impacts on regional carbonaceous aerosols: Case study in Central Texas. J. Air Waste Manage. Assoc. 64, 917-926.

Bergstrom, R.W., Pilewskie, P., Russell, P.B., Redemann, J., Bond, T.C., Quinn, P.K., Sierau, B., 2007. Spectral absorption properties of atmospheric aerosols. Atmos. Chem. Phys. 7, 5937-5943.

Blando, J.D., Turpin, B.J., 2000. Secondary organic aerosol formation in cloud and fog droplets: a literature evaluation of plausibility. Atmos. Environ. 34, 1623-1632.

Bond, T.C., 2001. Spectral dependence of visible light absorption by carbonaceous particles emitted from coal combustion. GeoRL. 28, 4075-4078.

Bones, D.L., Henricksen, D.K., Mang, S.A., Gonsior, M., Bateman, A.P., Nguyen, T.B., Cooper, W.J., Nizkorodov, S.A., 2010. Appearance of strong absorbers and fluorophores in limonene-O3secondary organic aerosol due to NH4+-mediated chemical aging over long time scales. J. Geophys. Res. 115.

Chen, Y., Bond, T.C., 2010. Light absorption by organic carbon from wood combustion. Atmos. Chem. Phys. 10, 1773-1787.

Decesari, S., Fuzzi, S., Facchini, M.C., Mircea, M., Emblico, L., Cavalli, F., Maenhaut, W., Chi, X., Schkolnik, G., Falkovich, A., Rudich, Y., Claeys, M., Pashynska, V., Vas, G., Kourtchev, I., Vermeylen, R., Hoffer, A., Andreae, M.O., Tagliavini, E., Moretti, F., Artaxo, P., 2006. Characterization of the organic composition of aerosols from Rondônia, Brazil, during the LBA-SMOCC 2002 experiment and its representation through model compounds. Atmos. Chem. Phys. 6, 375-402.

Du, Z., He, K., Cheng, Y., Duan, F., Ma, Y., Liu, J., Zhang, X., Zheng, M., Weber, R., 2014a. A yearlong study of water-soluble organic carbon in Beijing I: sources and its primary vs. secondary nature. Atmos. Environ. 92, 514-521.

Du, Z., He, K., Cheng, Y., Duan, F., Ma, Y., Liu, J., Zhang, X., Zheng, M., Weber, R., 2014b. A yearlong study of water-soluble organic carbon in Beijing II: Light absorption properties. Atmos. Environ. 89, 235-241.

Duarte, A.C., Duarte, R.M.B.O., Pio, C.A., 2005. Spectroscopic study of the water-soluble organic matter isolated from atmospheric aerosols collected under different atmospheric conditions. Anal. Chim. Acta 530, 7-14.

Dusek, U., Hitzenberger, R., Kasper-Giebl, A., Kistler, M., Meijer, H.A.J., Szidat, S. Wacker, L., Holzinger, R., Rockmann, T., 2017. Sources and formation mechanisms of carbonaceous aerosol at a regional background site in the Netherlands: insights from a year-long radiocarbon study. Atmos. Chem. Phys. 17, 3233-3251.

Ervens, B., Turpin, B.J., Weber, R.J., 2011. Secondary organic aerosol formation in cloud droplets and aqueous particles (aqSOA): a review of laboratory, field and model studies. Atmos. Chem. Phys. 11, 11069-11102.

Fang, T., Guo, H., Verma, V., Peltier, R.E., Weber, R.J., 2015. PM2.5 water-soluble elements in the southeastern United States: automated analytical method development, spatiotemporal distributions, source apportionment, and implications for heath studies. Atmos. Chem. Phys. 15, 11667-11682.

Feng, J., Li, M., Zhang, P., Gong, S., Zhong, M., Wu, M., Zheng, M., Chen, C., Wang, H., Lou, S., 2013. Investigation of the sources and seasonal variations of secondary organic aerosols in PM2.5 in Shanghai with organic tracers. Atmos. Environ. 79, 614-622.

Friese, E., Ebel, A., 2010. Temperature Dependent Thermodynamic Model of the System $\mathrm{H}+-\mathrm{NH} 4+-\mathrm{Na}+-\mathrm{SO} 42--\mathrm{NO} 3--\mathrm{Cl}--\mathrm{H} 2 \mathrm{O}$. J. Phys. Chem. A 114 , 11595-11631.

Fugaś, M., Gentilizza, M., 1978. The relationship between sulphate and Sulphur dioxide in the air. Atmospheric Environ. 12, 335-337.

Galloway, J.N., 1989. Atmospheric acidification: projections for the future. Ambio. 18, 161-166.

Gorham, E., Martin, F.B., Litzau, J.T., 1984. Acid rain: Ionic Correlations in the Eastern United States, 1980-1981. Science 225, 407-409.

Gu, J.X., Bai, Z.P., Liu, A.X., Wu, L.P., Xie, Y.Y., Li, W.F., Dong, H.Y., Zhang, X., 2010. Characterization of atmospheric organic carbon and element carbon of PM2.5 and PM10 at Tianjin, China. Aerosol Air Qual. Res. 10, 167-176.

Hallquist, M., Wenger, J.C., Baltensperger, U., Rudich, Y., Simpson, D., Claeys, M., Dommen, J., Donahue, N.M., George, C., Goldstein, A.H., Hamilton, J.F., Herrmann, H., Hoffmann, T., Iinuma, Y., Jang, M., Jenkin, M.E., Jimenez, J.L., Kiendler-Scharr, A., Maenhaut, W., McFiggans, G., Mentel, T.F., Monod, A., Prévôt, A.S.H., Seinfeld, J.H., Surratt, J.D., Szmigielski, R., Wildt, J., 2009. The formation, properties and impact of secondary organic aerosol: current and emerging issues. Atmos. Chem. Phys. 9, 5155-5236.

Hasheminassab, S., Daher, N., Saffari, A., Wang, D., Ostro, B.D., Sioutas, C., 2014. Spatial and temporal variability of sources of ambient fine particulate matter (PM2.5) in California. Atmos. Chem. Phys. 14, 12085-12097.

He, K., Yang, F., Ma, Y., Zhang, Q., Yao, X., Chan, C.K., Cadle, S., Chan, T., Mulawa, P., 2001. The characteristics of PM2.5 in Beijing, China. Atmos. Environ. 35, 4959-4970.

Hecobian, A., Zhang, X., Zheng, M., Frank, N., Edgerton, E.S., Weber, R.J., 2010. Watersoluble organic aerosol material and the light-absorption characteristics of aqueous extracts measured over the Southeastern United States. Atmos. Chem. Phys. 10, 5965-5977.

Hodas, N., Sullivan, A.P., Skog, K., Keutsch, F.N., Collett Jr., J.L., Decesari, S., Facchini, M.C., Carlton, A.G., Laaksonen, A., Turpin, B.J., 2014. Aerosol liquid water driven by anthropogenic nitrate: implications for lifetimes of water-soluble organic gases and potential for secondary organic aerosol formation. Environ. Sci. Technol. 48,
11127-11136.

Hoffer, A., Gelencsér, A., Guyon, P., Kiss, G., Schmid, O., Frank, G.P., Artaxo, P., Andreae, M.O., 2006. Optical properties of humic-like substances (HULIS) in biomass-burning aerosols. Atmos. Chem. Phys. 6, 3563-3570.

Huang, X.-F., Yu, J.Z., He, L.-Y., Yuan, Z., 2006. Water-soluble organic carbon and oxalate in aerosols at a coastal urban site in China: size distribution characteristics, sources, and formation mechanisms. J. Geophys. Res. - Atmos. 111, D22212.

Huang, H., Ho, K.F., Lee, S.C., Tsang, P.K., Ho, S.S.H., Zou, C.W., Zou, S.C., Cao, J.J., Xu, H.M., 2012. Characteristics of carbonaceous aerosol in PM2.5: Pearl Delta River Region, China. Atmos. Res. 104-105, 227-236.

Jaffrezo, J.-L., Aymoz, G., Delaval, C., Cozic, J., 2005. Seasonal variations of the Water Soluble Organic Carbon mass fraction of aerosol in two valleys of the French Alps. Atmos. Chem. Phys. 5.

Jang, M., Czoschke, N.M., Lee, S., Kamens, R.M., 2002. Heterogeneous atmospheric aerosol production by acid-catalyzed particle-phase reactions. Science 298, 814-817.

Jiang, N., Guo, Y., Wang, Q., Kang, P., Zhang, R., Tang, X., 2017. Chemical Composition Characteristics of PM2.5 in three Cities in Henan, Central China. Aerosol Air Qual. Res. 17, 2367-2380.

Jiang, N., Li, Q., Su, F., Wang, Q., Yu, X., Kang, P., Zhang, R., Tang, X., 2018. Chemical characteristics and source apportionment of PM2.5 between heavily polluted days and other days in Zhengzhou, China. JEnvS. 66, 188-198.

Kanakidou, M., Seinfeld, J.H., Pandis, S.N., Barnes, I., Dentener, F.J., Facchini, M.C., Van Dingenen, R., Ervens, B., Nenes, A., Nielsen, C.J., Swietlicki, E., Putaud, J.P., Balkanski, Y., Fuzzi, S., Horth, J., Moortgat, G.K., Winterhalter, R., Myhre, C.E.L., Tsigaridis, K., Vignati, E., Stephanou, E.G., Wilson, J., 2005. Organic aerosol and global climate modelling: a review. Atmos. Chem. Phys. 5, 1053-1123.

Kawamura, K., Kasukabe, H., Barrie, L.A., 2010. Secondary formation of water-soluble organic acids and $\alpha$-dicarbonyls and their contributions to total carbon and watersoluble organic carbon: Photochemical aging of organic aerosols in the Arctic spring. J. Geophys. Res.-Atmos. 115.

Kirchstetter, T.W., Novakov, T., Hobbs, P.V., 2004. Evidence that the spectral dependence of light absorption by aerosols is affected by organic carbon. J. Geophys. Res. Atmos. 109 (D21), D21208.

Kirillova, E.N., Andersson, A., Han, J., Lee, M., Gustafsson, Ã., Stockholms, U., Naturvetenskapliga, F., Institutionen för tillämpad, M, 2014. Sources and light absorption of water-soluble organic carbon aerosols in the outflow from northern China. Atmos. Chem. Phys. 14, 1413-1422.

Kirillova, E.N., Andersson, A., Sheesley, R.J., Krusa, M., Praveen, P.S., Budhavant, K., Safai, P.D., Rao, P.S.P., Gustafsson, O., Stockholms, U., Naturvetenskapliga, F., Institutionen för tillämpad, M, 2013. C-13- and C-14-based study of sources and atmospheric processing of water-soluble organic carbon (WSOC) in South Asian aerosols. J. Geophys. Res. - Atmos. 118, 614-626.

Kondo, Y., Miyazaki, Y., Takegawa, N., Miyakawa, T., Weber, R., Jimenez, J.L., Zhang, Q. Worsnop, D., 2007. Oxygenated and water-soluble organic aerosols in Tokyo. J. Geophys. Res.-Atmos. 112.

Li, T., Wang, Y., Li, W.J., Chen, J.M., Wang, T., Wang, W.X., 2015. Concentrations and solubility of trace elements in fine particles at a mountain site, southern China: regional sources and cloud processing. Atmos. Chem. Phys. 15, 8987-9002.

Li, J.Y., Michalski, G., Davy, P., Harvey, M., Katzman, T., Wilkins, B., 2018. Investigating Source Contributions of Size-Aggregated Aerosols Collected in Southern Ocean and Baring Head, New Zealand using Sulfur Isotopes. GeoRL. 45, 3717-3727.

Lim, Y.B., Tan, Y., Perri, M.J., Seitzinger, S.P., Turpin, B.J., 2010. Aqueous chemistry and its role in secondary organic aerosol (SOA) formation. Atmos. Chem. Phys. 10, 10521-10539.

Liu, J., Bergin, M., Guo, H., King, L., Kotra, N., Edgerton, E., Weber, R.J., 2013. Sizeresolved measurements of brown carbon in water and methanol extracts and estimates of their contribution to ambient fine-particle light absorption. Atmos. Chem. Phys. 13, 12389-12404.

Liu, B., Song, N., Dai, Q., Mei, R., Sui, B., Bi, X., Feng, Y., 2016. Chemical composition and source apportionment of ambient PM2.5 during the non-heating period in Taian, China. Atmos. Res. 170, 23-33.

Luo, Y., Zhou, X., Zhang, J., Xiao, Y., Wang, Z., Zhou, Y., Wang, W., 2018. PM2.5 pollution in a petrochemical industry city of northern China: Seasonal variation and source apportionment. Atmos. Res. 212, 285-295.

Ma, H.M., Li, J., Wan, C., Liang, Y.H., Zhang, X.Y., Dong, G.H., Hu, L.W., Yang, B.Y., Zeng, X.W., Su, T., Lu, S.Y., Chen, S.J., Khorram, M.S., Sheng, G.Y., Wang, X.M., Mai, B.X., Yu, Z.Q., Zhang, G., 2019. Inflammation response of water-soluble fractions in atmospheric fine particulates: a seasonal observation in 10 large Chinese Cities Environ. Sci. Technol. 53, 3782-3790.

Niu, Z., Zhang, F., Chen, J., Yin, L., Wang, S., Xu, L., 2013. Carbonaceous species in PM2.5 in the coastal urban agglomeration in the Western Taiwan Strait Region, China. Atmos. Res. 122, 102-110.

Panteliadis, P., Hafkenscheid, T., Cary, B., Diapouli, E., Fischer, A., Favez, O., Quincey, P., Viana, M., Hitzenberger, R., Vecchi, R., Saraga, D., Sciare, J., Jaffrezo, J.L., John, A., Schwarz, J., Giannoni, M., Novak, J., Karanasiou, A., Fermo, P., Maenhaut, W., 2015. ECOC comparison exercise with identical thermal protocols after temperature offset correction - instrument diagnostics by in-depth evaluation of operational parameters. Atmos. Measure. Techniques 8, 779-792.

Park, S.S., Cho, S.Y., 2011. Tracking sources and behaviors of water-soluble organic carbon in fine particulate matter measured at an urban site in Korea. Atmos. Environ. 45, 60-72.

Pathak, R.K., Wang, T., Ho, K.F., Lee, S.C., 2011. Characteristics of summertime PM2.5 organic and elemental carbon in four major Chinese cities: Implications of high acidity for water-soluble organic carbon (WSOC). Atmos. Environ. 45, 318-325.

Pöschl, U., Martin, S., Sinha, B., Chen, Q., Gunthe, S., Huffman, J., Borrmann, S., Farmer, D., Garland, R., Helas, G., 2010. Rainforest aerosols as biogenic nuclei of clouds and 
precipitation in the Amazon. Sci. 329, 1513-1516.

Rengarajan, R., Sudheer, A.K., Sarin, M.M., 2011. Aerosol acidity and secondary organic aerosol formation during wintertime over urban environment in western India. Atmos. Environ. 45, 1940-1945.

Snyder, D., Rutter, A., Collins, R., Worley, C., Schauer, J., 2009. Insights into the Origin of Water Soluble Organic Carbon in Atmospheric Fine Particulate Matter.

Srinivas, B., Sarin, M.M., 2013. Light absorbing organic aerosols (brown carbon) over the tropical Indian Ocean: Impact of biomass burning emissions. Environ. Res. Lett. 8, 44042.

Stelson, A.W., Friedlander, S.K., Seinfeld, J.H., 1979. A note on the equilibrium relationship between ammonia and nitric acid and particulate ammonium nitrate. Atmospheric Environ. 13, 369-371.

Sullivan, A.P., Weber, R.J., 2006. Chemical characterization of the ambient organic aerosol soluble in water: 1 . Isolation of hydrophobic and hydrophilic fractions with a XAD-8 resin. J. Geophys. Res.-Atmos. 111.

Sun, Y.L., Zhang, Q., Anastasio, C., Sun, J., 2010. Insights into secondary organic aerosol formed via aqueous-phase reactions of phenolic compounds based on high resolution mass spectrometry. Atmos. Chem. Phys. 10, 4809-4822.

Surratt, J., Lewandowski, M., Offenberg, J., Jaoui, M., Kleindienst, T., Edney, E., H Seinfeld, J., 2007. Effect of acidity on secondary organic aerosol formation from isoprene. Environ. Sci. Technol. 41, 5363-5369.

Taghvaee, S., Sowlat, M.H., Diapouli, E., Manousakas, M.I., Vasilatou, V., Eleftheriadis, K., Sioutas, C., 2019. Source apportionment of the oxidative potential of fine ambient particulate matter (PM2.5) in Athens, Greece. Sci. Total Environ. 653, 1407-1416.

Teich, M., van Pinxteren, D., Wang, M., Kecorius, S., Wang, Z., Müller, T., Mocnik, G., Herrmann, H., 2016. Contributions of nitrated aromatic compounds to the light absorption of water-soluble and particulate brown carbon in different atmospheric environments in Germany and China. Atmos. Chem. Phys. Discuss. 1-24.

Verma, V., Fang, T., Xu, L., Peltier, R.E., Russell, A.G., Ng, N.L., Weber, R.J., 2015. Organic Aerosols Associated with the Generation of Reactive Oxygen Species (ROS) by Water-Soluble PM2.5. Environ. Sci. Technol. 49, 4646-4656.

Viana, M., López, J.M., Querol, X., Alastuey, A., García-Gacio, D., Blanco-Heras, G., López-Mahía, P., Piñeiro-Iglesias, M., Sanz, M.J., Sanz, F., Chi, X., Maenhaut, W., 2008. Tracers and impact of open burning of rice straw residues on PM in Eastern Spain. Atmos. Environ. 42, 1941-1957.

Wang, X., Mauzerall, D.L., Hu, Y., Russell, A.G., Larson, E.D., Woo, J.-H., Streets, D.G., Guenther, A., 2005. A high-resolution emission inventory for eastern China in 2000 and three scenarios for 2020. Atmos. Environ. 39, 5917-5933.

Wang, X., Wang, W., Yang, L., Gao, X., Nie, W., Yu, Y., Xu, P., Zhou, Y., Wang, Z., 2012. The secondary formation of inorganic aerosols in the droplet mode through heterogeneous aqueous reactions under haze conditions. Atmos. Environ. 63, 68-76.

Wang, Z., Zhao, J., Niu, Z., 2017. Influence of Air Pollution on the Outpatient volume of Cardiovascular and Cerebrovascular Diseases using the Poisson Generalized Additive Models in Weifang. Chin. J. Health Stat. 34, 232-235.

Wang, C., An, X., Zhai, S., Sun, Z., 2018. Tracking a Severe Pollution Event in Beijing in December 2016 with the GRAPES-CUACE Adjoint Model. J. Meteorol. Res. 32, 49-59.

Watson, J.G., Chow, J.C., Houck, J.E., 2001. PM2.5 chemical source profiles for vehicle exhaust, vegetative burning, geological material, and coal burning in Northwestern Colorado during 1995. Chemosphere. 43, 1141-1151.

Wexler, A.S., Clegg, S.L., 2002. Atmospheric aerosol models for systems including the ions $\mathrm{H}+, \mathrm{NH} 4+, \mathrm{Na}+, \mathrm{SO} 42-, \mathrm{NO} 3-, \mathrm{Cl}-, \mathrm{Br}-$, and H2O. J. Geophys. Res.-Atmos. 107 (ACH 14-11-ACH 14-14).

Wu, R., Zhou, X., Wang, L., Wang, Z., Zhou, Y., Zhang, J., Wang, W., 2017. PM2.5 Characteristics in Qingdao and across Coastal Cities in China. Atmosphere.- Basel. $8,77$.

Xiang, P., Zhou, X., Duan, J., Tan, J., He, K., Yuan, C., Ma, Y., Zhang, Y., 2017. Chemical characteristics of water-soluble organic compounds (WSOC) in PM2.5 in Beijing, China: 2011-2012. Atmos. Res. 183, 104-112.

Xiao, R., Takegawa, N., Zheng, M., Kondo, Y., Miyazaki, Y., Miyakawa, T., Hu, M., Shao,
M., Zeng, L., Gong, Y., 2011. Characterization and source apportionment of submicron aerosol with aerosol mass spectrometer during the PRIDE-PRD $2006 \mathrm{cam}$ paign. Atmos. Chem. Phys. 11, 6911-6929.

Xing, J., Cui, K.P., Tang, H.Y., Lee, W.J., Wang, L.C., Zhu, J.N., Huang, Q.L., 2017. Part II: PM2.5 and polychlorinated dibenzo-p-dioxins and dibenzofurans (PCDD/Fs) in the ambient air of Northern China. Aerosol Air Qual. Res. 17, 2010-2026.

Yang, M., Howell, S.G., Zhuang, J., Huebert, B.J., 2009. Attribution of aerosol light absorption to black carbon, brown carbon, and dust in China - Interpretations of atmospheric measurements during EAST-AIRE. Atmos. Chem. Phys. 9, 2035-2050.

Yang, L., Zhou, X., Wang, Z., Zhou, Y., Cheng, S., Xu, P., Gao, X., Nie, W., Wang, X., Wang, W., 2012. Airborne fine particulate pollution in Jinan, China: Concentrations, chemical compositions and influence on visibility impairment. Atmos. Environ. 55, 506-514.

Yang, F., Gu, Z., Feng, J., Liu, X., Yao, X., 2014. Biogenic and anthropogenic sources of oxalate in PM2.5 in a mega city, Shanghai. Atmos. Res. 138, 356-363.

Yao, X., Fang, M., Chan, C.K., 2002. Size distributions and formation of dicarboxylic acids in atmospheric particles. Atmos. Environ. 36, 2099-2107.

Yao, L., Yang, L.X., Yuan, Q., Yan, C., Dong, C., Meng, C.P., Sui, X., Yang, F., Lu, Y.L., Wang, W.X., 2016. Sources apportionment of PM2.5 in a background site in the North China Plain. Sci. Total Environ. 541, 590-598.

Yu, L., Smith, J., Laskin, A., Anastasio, C., Laskin, J., Zhang, Q., 2014. Chemical characterization of SOA formed from aqueous-phase reactions of phenols with the triplet excited state of carbonyl and hydroxyl radical. Atmos. Chem. Phys. 14, $13801-13816$.

Yuan, Q., Yang, L., Dong, C., Yan, C., Meng, C., Sui, X., Wang, W., 2014. Temporal variations, acidity, and transport patterns of PM2.5 ionic components at a background site in the Yellow River Delta, China. Air. Qual.Atmos. Hlth. 7, 143-153.

Zhang, Q., L Jimenez, J., Worsnop, D., Canagaratna, M., 2007. A case study of urban particle acidity and its influence on secondary organic aerosol. Environ. Sci. Technol. 41, 3213-3219.

Zhang, R., Jing, J., Tao, J., Hsu, S.C., Wang, G., Cao, J., Lee, C.S.L., Zhu, L., Chen, Z. Zhao, Y., Shen, Z., 2013. Chemical characterization and source apportionment of PM2.5 in Beijing: Seasonal perspective. Atmos. Chem. Phys. 13, 7053-7074.

Zhang, Y., Cai, J., Wang, S., He, K., Zheng, M., 2017a. Review of receptor-based source apportionment research of fine particulate matter and its challenges in China. Sci. Total Environ. 586, 917-929.

Zhang, Y., Xu, J., Shi, J., Xie, C., Ge, X., Wang, J., Kang, S., Zhang, Q., 2017b. Light absorption by water-soluble organic carbon in atmospheric fine particles in the central Tibetan Plateau. Environ. Sci. Pollut. Res. 24, 21386-21397.

Zhang, J., Zhou, X., Wang, W., Wang, Z., Wang, J., Yang, L., 2018a. Trace elements in PM2.5 in Shandong Province: source identification and health risk assessment. Sci. Total Environ. 621, 558-577.

Zhang, Y., Sun, J., Zheng, P., Chen, T., Liu, Y., Han, G., Simpson, I.J., Wang, X., Blake, D.R., Li, Z., Yang, X., Qi, Y., Wang, Q., Wang, W., Xue, L., 2018b. Observations of C1C5 alkyl nitrates in the Yellow River Delta, northern China: Effects of biomass burning and oil field emissions. Sci. Total Environ. 656, 129-139.

Zhao, R., Mungall, E.L., Lee, A.K.Y., Aljawhary, D., Abbatt, J.P.D., 2014. Aqueous-phase photooxidation of levoglucosan - a mechanistic study using aerosol time-of-flight chemical ionization mass spectrometry (aerosol ToF-CIMS). Atmos. Chem. Phys. 14, 9695-9706.

Zhao, Z.Z., Cao, J.J., Shen, Z.X., Huang, R.J., Hu, T.F., Wang, P., Zhang, T., Liu, S.X., 2015. Chemical composition of PM2.5 at a high-altitude regional background site over Northeast of Tibet Plateau. Atmos. Pollut. Res. 6, 815-823.

Zhao, C., Niu, M.Y., Song, S.Y., Li, J., Su, Z.L., Wang, Y., Gao, Q., Wang, H.W., 2019. Serum metabolomics analysis of mice that received repeated airway exposure to a water-soluble PM2.5 extract. Ecotoxicol. Environ. Saf. 168, 102-109.

Zhou, J.M., Zhang, R.J., Cao, J.J., Chow, J.C., Watson, J.G., 2012. Carbonaceous and ionic components of atmospheric fine particles in beijing and their impact on atmospheric visibility. Aerosol Air Qual. Res. 12, 492-502. 